\title{
Targeted Radionuclide Therapy Using Auger Electron Emitters: The Quest for the Right Vector and the Right Radionuclide
}

\author{
Malick Bio Idrissou ${ }^{1}$, Alexandre Pichard ${ }^{1}$, Bryan Tee ${ }^{2} \oplus$, Tibor Kibedi ${ }^{2}$, Sophie Poty ${ }^{1}$ and Jean-Pierre Pouget ${ }^{1, *}$ \\ 1 Institut de Recherche en Cancérologie de Montpellier, Inserm U1194, Université de Montpellier, \\ Institut Régional du Cancer de Montpellier, 34298 Montpellier, France; malick.bio-idrissou@inserm.fr (M.B.I.); \\ alexandre.pichard@inserm.fr (A.P.); sophie.poty@inserm.fr (S.P.) \\ 2 Department of Nuclear Physics, Research School of Physics, Australian National University, \\ Canberra, ACT 2601, Australia; Bryan.Tee@anu.edu.au (B.T.); Tibor.Kibedi@anu.edu.au (T.K.) \\ * Correspondence: jean-pierre.pouget@inserm.fr
}

Citation: Idrissou, M.B.; Pichard, A.; Tee, B.; Kibedi, T.; Poty, S.; Pouget, J.-P. Targeted Radionuclide Therapy Using Auger Electron Emitters: The Quest for the Right Vector and the Right Radionuclide. Pharmaceutics 2021, 13, 980. https://doi.org/ 10.3390/pharmaceutics13070980

Academic Editor: Yann Seimbille

Received: 22 April 2021

Accepted: 24 June 2021

Published: 29 June 2021

Publisher's Note: MDPI stays neutral with regard to jurisdictional claims in published maps and institutional affiliations.

Copyright: (c) 2021 by the authors. Licensee MDPI, Basel, Switzerland. This article is an open access article distributed under the terms and conditions of the Creative Commons Attribution (CC BY) license (https:/ / creativecommons.org/licenses/by/ $4.0 /)$.

\begin{abstract}
Auger electron emitters (AEEs) are attractive tools in targeted radionuclide therapy to specifically irradiate tumour cells while sparing healthy tissues. However, because of their short range, AEEs need to be brought close to sensitive targets, particularly nuclear DNA, and to a lower extent, cell membrane. Therefore, radioimmunoconjugates (RIC) have been developed for specific tumour cell targeting and transportation to the nucleus. Herein, we assessed, in A-431 CEA-luc and SK-OV-3 ${ }_{1 \mathrm{~B} 9}$ cancer cells that express low and high levels of HER2 receptors, two ${ }^{111}$ In-RIC consisting of the anti-HER2 antibody trastuzumab conjugated to NLS or TAT peptides for nuclear delivery. We found that NLS and TAT peptides improved the nuclear uptake of ${ }^{111}$ In-trastuzumab conjugates, but this effect was limited and non-specific. Moreover, it did not result in a drastic decrease of clonogenic survival. Indium-111 also contributed to non-specific cytotoxicity in vitro due to conversion electrons (30\% of the cell killing). Comparison with $\left[{ }^{125} \mathrm{I}\right] \mathrm{I}-\mathrm{UdR}$ showed that the energy released in the cell nucleus by increasing the RIC's nuclear uptake or by choosing an AEE that releases more energy per decay should be 5 to 10 times higher to observe a significant therapeutic effect. Therefore, new Auger-based radiopharmaceuticals need to be developed.
\end{abstract}

Keywords: Auger electrons; nuclear localisation sequence; NLS peptide; TAT peptide; radionuclide therapy

\section{Introduction}

Targeted radionuclide therapy (TRT) is an attractive approach to treat cancer because it allows the specific irradiation of tumour cells. As, theoretically, TRT spares healthy tissues that do not express high levels of the targeted receptor, it represents a method of choice for treating diffuse and metastatic disease [1,2]. Historically, radiopharmaceuticals administered to treat patients have been based on beta-particle emitters, such as iodine-131 ( $\left.{ }^{131} \mathrm{I}\right)$ in thyroid carcinoma and phosphorus-32 $\left({ }^{32} \mathrm{P}\right)$ in ovarian cancer. Later, [90 Y]Y-ibritumomab tiuxetan (Zevalin) and [ $\left.{ }^{131} \mathrm{I}\right] \mathrm{I}$-tositumomab (Bexxar) were approved for radioimmunotherapy of non-Hodgkin B lymphoma. More recently, $\left[{ }^{177} \mathrm{Lu}\right] \mathrm{Lu}$-DOTATATE was also approved for therapy of neuroendocrine tumours [3], [ ${ }^{177} \mathrm{Lu}$ ]Lu-PSMA-617 for metastatic castration-resistant prostate cancer [4], and many clinical trials are currently assessing this radiopharmaceutical. Beta-particle emitters are largely available, at reasonable costs, and they are easy to chelate. However, although their relatively long range $(\geq 1 \mathrm{~mm})$ can counterbalance heterogeneity in radiopharmaceutical tumour distribution, it can also cause non-specific irradiation of healthy cells/tissues, thus limiting their interest for TRT. Moreover, beta particles are low linear energy transfer (LET) particles (like X and gamma rays). This means that they have a low ionising power and produce simple lesions in cells that can be repaired. Therefore, they can show limited efficacy against radioresistant solid tumours. This can be overcome by using high LET alpha particles, such as those 
emitted by radium-223 or by actinium-225, which have been tested for the management of prostate-cancer bone metastases. In addition, alpha-particle emitters decay according to a chain of disintegration, leading to several daughters that enhance therapeutic efficacy. Some questions remain, such as the choice of radionuclides, the stability of chelation, and the fate of daughters. Moreover, due to their range in matter (50-100 $\mu \mathrm{m})$, alpha particles can also cause some non-specific irradiation. Auger electron emitters $\left(\mathrm{AEE}_{\mathrm{S}}\right)$, another class of therapeutic radionuclides, also have generated much interest and could mitigate the non-specific irradiation issue. Auger electrons are emitted in cascades by atoms decaying by electron capture and/or conversion processes that usually produce vacancies in K shells. These vacancies are filled by electrons dropping from the outer shells. These transitions are accompanied by a release of energy that can be transferred to electrons of external layers emitted in cascades (Auger electron cascades) or emitted as fluorescent X-rays.

The energy of Auger electrons can reach tens of keV, but most of them have a very low energy $(<1 \mathrm{keV})$ that is released in a sphere of few cubic nanometres. Therefore, they are considered medium to high linear energy transfer (LET) particles $(4-26 \mathrm{keV} / \mu \mathrm{m})$. These high energy deposits produce locally dense ionisations that are very destructive when the radionuclide is incorporated in nuclear DNA, [5-8] the cell nucleus [9-13], or the cell membrane [14-19]. In a context where specific nuclear DNA targeting is still challenging, our group previously showed that AEE-based TRT with ${ }^{125}$ I-labelled non-internalising monoclonal antibodies (mAbs) against carcinoembryonic antigen (CEA) leads to significant tumour growth delay in preclinical mouse models harbouring small tumours [18]. While nuclear targeting directly mediates the DNA damage response (DDR) leading to cell death, Auger electron cascades produced at the cell membrane induce the local formation of ceramide-enriched large domains (lipid rafts) that activate signalling pathways involving NF-kB and ultimately, leading to reactive oxygen species (ROS) production, nuclear damage, and DDR activation $[15,19]$. We also demonstrated that bystander effects induced by nuclear (5-[ ${ }^{125}$ I] iodo-2'-deoxyuridine, $\left.\left[{ }^{125} \mathrm{I}\right] \mathrm{I}-\mathrm{UdR}\right)$ and cell membrane (non-internalising ${ }^{125} \mathrm{I}-\mathrm{mAbs}$ ) irradiation contribute significantly to cell death $[13,15]$. Notably, we showed that, after incubation with the DNA base analogue [ $\left.{ }^{125} \mathrm{I}\right] \mathrm{I}-\mathrm{UdR}, 30-35 \%$ of cells were killed by bystander effects and $50 \%$ of cells by the direct effect of Auger electrons.

AEEs could be a precious asset for TRT, but there has not been, so far, any convincing candidate, although about $50 \%$ of radionuclides emit AEs. Indeed, a major advantage of AEE-based TRT is to decrease the non-specific irradiation of healthy tissues, while benefiting from Auger electrons' high LET features. However, due to their short range and lack of cross-fire irradiation in tumours, AAE-based TRT might require the administration of high activities or repeated administrations to counterbalance the radionuclide distribution heterogeneity that would not allow reaching all tumour cells after one single administration. Therefore, ideal AEE should not emit (or may emit only in very low proportion) other radiation types $(\gamma, \beta, C E)$, responsible for non-specific irradiations, as these would overwhelm AEE-TRT's benefits. AEE also need to locally release high amount of energy, a parameter that is influenced by the number of Auger electrons released per decay and their average energy. Iodine-125, which emits about 20 Auger electrons/decay and releases low amount of energy through the emission of conversion electrons (CE) or photons, is a very attractive AEE candidate. Iodine-125 radiopharmaceuticals have been developed ([ $\left.{ }^{125} \mathrm{I}\right] \mathrm{I}-\mathrm{UdR}$ or mAbs conjugates) [20-23], but their clinical use is limited by ${ }^{125} \mathrm{I}^{\prime} \mathrm{s}$ long physical half-life $\left(\mathrm{t}_{1 / 2 \text { (Phys) }}=59.4\right.$ days). A comprehensive list of AEE candidates has recently been reviewed in [24]. Platinum-193 $\mathrm{m}\left(\mathrm{t}_{1 / 2}\right.$ (phys) $=4.3$ days) and platinum-195 $\mathrm{m}\left(\mathrm{t}_{1 / 2 \text { (phys) }}=4.0\right.$ days) also are very attractive AEEs because they emit a very high number of Auger electrons (between 20 and 30) per decay and photons of intermediate energy (66 and $76 \mathrm{keV}$ ) than can be used for imaging. However, they are still not routinely available, and the radiolabelling of biological vectors is still challenging. Many studies have used indium-111 because it has a short physical half-life (2.8 days), is easily conjugated to macromolecules, and is easily produced [25]. However, ${ }^{111}$ In is a poor AEE with about 7-8 Auger electrons per decay, emission of energetic CEs (0.16 per decay; average energy $=176 \mathrm{keV}$ ) and $\gamma$-rays 
(1.85 energetic photons of 171.28 and $245.35 \mathrm{keV}$ per decay) that can cause non-specific irradiation and raise radiation protection concerns, respectively.

Another difficulty with AEEs is the need to build radioimmunoconjugates (RIC) that can specifically target cancer cells and also drive activity at least into the nucleus, if not into DNA. Indeed, as Auger electrons with high LET have a range of few nm, nuclear localisation without incorporation into DNA would lead to a significant decrease in efficacy, although the results might still be acceptable.

Herein, we assessed two new ${ }^{111}$ In-RICs based on the anti-HER2 antibody trastuzumab functionalised with two cationic peptides (NLS and TAT) harbouring a nuclear localising sequence. Pioneering groups have shown that these peptides allow the nuclear transportation of the functionalised antibodies in AEE-based TRT settings [11,26,27]. Although, other authors highlighted the need for alternative approaches to improve their delivery [28-30], none of these approaches has been evaluated beyond the preclinical stage. Moreover, only one study investigated [ ${ }^{111}$ In]In-DTPA-human epidermal growth factor in patients [31] but did not confirm the promising results obtained in animal models [28]. In this study, we evaluated whether NLS-/TAT-immunoconjugates are suitable vectors to specifically deliver AEE-based TRT to the cancer cell nucleus. We hypothesised that the ${ }^{111}$ In-trastuzumab RIC specifically targets HER2-positive cancer cells before internalization in the cell cytoplasm. When conjugated to NLS or TAT peptides, the nuclear localisation signal should drive this RIC through the nuclear pore complex to enhance Auger electron cytotoxicity. To test this hypothesis, we thoroughly investigated the subcellular localisation, activity uptake, and cytotoxic effects of the developed ${ }^{111}$ In-RICs.

\section{Materials and Methods}

\subsection{Cell Lines}

A-431 vulvar squamous carcinoma and SK-OV-3 ovarian carcinoma cells were obtained from the American Type Culture Collection (ATCC, Rockville, MD, USA). HER1and HER2-expressing A-431 cells were transfected with the genes encoding CEA and luciferase to obtain the A-431 $1_{\mathrm{CEA}-\text { luc }}$ cell line, as previously described [14]. HER1- and HER2-expressing SK-OV-3 cells were transfected with the gene encoding CEA to obtain the SK-OV- $3_{1 \mathrm{~B} 9}$ cell line. All cell lines were grown in DMEM supplemented with $10 \%$ heatinactivated foetal bovine serum, $1 \%$ penicillin/streptomycin, and $200 \mu \mathrm{g} / \mathrm{mL}$ geneticin. Hygromycin $(100 \mu \mathrm{g} / \mathrm{mL})$ was added to the medium for A-431 CEA-luc cells. Cell lines were routinely tested for mycoplasma contamination using the MycoTect assay from Life technologies (Thermo Fisher Scientific, Waltham, MA, USA).

\subsection{Antibodies and Peptides}

Trastuzumab (Herceptin, Roche, Basel, Switzerland) is a humanised IgG1k mAb against the HER2 receptor. A humanised anti-AMHRII IgG1 mAb, 3C23K, was used as an irrelevant $\mathrm{mAb}$, derived from the murine anti-AMHRII mAb 12G4 [32].

The 16-mer TAT peptide [GRKKRRQRRRPPQGYG] harbouring the nuclear localisation sequence (underlined) of the HIV-1 tat protein was synthesised and provided by Genscript Biotech (Leiden, The Netherlands) with a purity $\geq 90 \%$. The 13-mer Simian Virus 40 T-Ag-derived NLS peptide [CGYGPKKKRKVGG] (the nuclear localisation sequence is underlined) was synthesised and provided by Proteogenix (Schiltigheim, France) with a purity of $90.40 \%$. Both peptides were redissolved in chelexed PBS (pH 7.2) at a concentration of $7 \mathrm{mg} / \mathrm{mL}$ and kept at $-80{ }^{\circ} \mathrm{C}$ until use.

\subsection{Bioconjugation, Radiolabelling, Purification and Quality Control}

Trastuzumab and the irrelevant humanised IgG (3C23K) were conjugated to $p-S C N-B n$ CHX-A"-DTPA ([(R)-2-amino-3-(4-isothiocyanatophenyl)propyl]-trans-(S,S)-cyclohexane1,2-diamine-pentaacetic acid), provided by Macrocyclics (Plano, TX, USA), a chelating agent allowing further radiolabelling with ${ }^{111} \mathrm{In}$. Briefly, the $\mathrm{pH}$ of the trastuzumab and $\mathrm{IgG}$ solutions (2-8 mg in chelexed PBS; $8-12 \mathrm{mg} / \mathrm{mL}$ ) was adjusted to 8.4 using a $0.2 \mathrm{M}$ chelexed 
$\mathrm{Na}_{2} \mathrm{CO}_{3}$ solution (pH 10). A 15 -fold molar excess of $p$-SCN-Bn-CHX-A"-DTPA $(25 \mathrm{mg} / \mathrm{mL}$ in DMSO) was added drop by drop $(2 \mu \mathrm{L})$ to prevent precipitation. Bioconjugation was performed at $37^{\circ} \mathrm{C}$ for $90 \mathrm{~min}$, followed by purification on an Amicon $30 \mathrm{kDa}$ (Merck Millipore, Molsheim, France) and chelexed PBS washes (pH 7.2).

The NLS and TAT peptides were conjugated to DTPA-modified trastuzumab or IgG using the heterobifunctional cross-linking agent sulphosuccinimidyl-4-(N-maleimidomethyl) cyclohexane-1-carboxylate (sulpho-SMCC; Thermo Fisher Scientific, Rockford, IL, USA). Briefly, DTPA-trastuzumab or DTPA-IgG (chelexed PBS, pH 7.2) was mixed with 25- to 50 -fold molar excess of sulpho-SMCC dissolved to $2.34 \mathrm{mg} / \mathrm{mL}$ in Ultra Trace Elemental Analysis Grade water (Thermo Fisher Scientific, Illkirch-Graffenstaden, France) at room temperature (RT) for $60 \mathrm{~min}$. The obtained activated-ester DTPA-trastuzumab or IgG conjugates were transferred to Amicon $30 \mathrm{kDa}$ (Merck Millipore, Burlington, MA, USA), purified, and concentrated to $3-7 \mathrm{mg} / \mathrm{mL}$ with chelexed PBS (pH 7.5). Then, conjugates were mixed with 40 - to 60 -fold molar excess of NLS or TAT peptides $(7 \mathrm{mg} / \mathrm{mL}$ in chelexed PBS [pH 7.2]) at $37^{\circ} \mathrm{C}$ for $90 \mathrm{~min}$. The final conjugates were transferred to Amicon 30 $\mathrm{kDa}$ (Merck Millipore), and the PBS buffer was exchanged to ammonium acetate $(0.25 \mathrm{M}$, $\mathrm{pH}$ 5.5) with two consecutive washes.

Matrix-assisted laser desorption ionisation-time of flight (MALDI-TOF) was used to determine the number of DTPA, SMCC, NLS, or TAT moieties per antibody. The $\mathrm{m} / \mathrm{z}$ difference between the native $\mathrm{mAbs}$ and their conjugates was divided by the molecular weight of the added functional group (DTPA, sulpho-SMCC, or peptide) to find the chelate/peptide-to-antibody ratio.

HER2-specific immunoconjugates (DTPA-trastuzumab, DTPA-trastuzumab-NLS, and DTPA-trastuzumab-TAT) (Figure 1a) and irrelevant immunoconjugates (DTPA-IgG, DTPAIgG-NLS, and DTPA-IgG-TAT) were labelled with indium-111 ([111 $\left.\mathrm{In}] \mathrm{InCl}_{3}\right)$ to obtain a specific activity of $370 \mathrm{MBq} / \mathrm{mg}$. Typically, $119 \mu \mathrm{L}$ (100 MBq) of [ $\left.{ }^{111} \mathrm{In}\right] \mathrm{InCl}_{3}$ (in $\mathrm{HCl} 0.05 \mathrm{~N}$; Curium, Paris, France) were mixed with $119 \mu \mathrm{L} 0.25 \mathrm{M}$ ammonium acetate (pH 5.5) to stabilise the $\mathrm{pH}$ at 5.5. Then, $270 \mu \mathrm{g}$ (volume $(\mu \mathrm{L})$, depending on the concentration) of immunoconjugate were added at $37^{\circ} \mathrm{C}$ for $90 \mathrm{~min}$. Radiolabelling yields and radiochemical purity were determined by instant thin-layer silica-gel chromatography (iTLC, Montpellier, France) with $50 \mathrm{mM}$ EDTA (pH 5.5) as eluant. RICs were purified using a desalting PD-10 column and eluted with PBS. All RICs were successfully obtained, with radiochemical yields between 80 and $98 \%$ and specific activities ranging from 310 to $380 \mathrm{MBq} / \mathrm{mg}$.

\subsection{Immunoconjugates Cell Binding and HER2 Cell Expression}

Immunoconjugate cell binding was assessed by flow cytometry. Cells were fixed with $4 \%(v / v)$ paraformaldehyde in PBS at RT for $15 \mathrm{~min}$, permeabilised with Triton X100 (0.5\% in PBS) at RT for $15 \mathrm{~min}$, and blocked with PBS/bovine serum albumin (BSA) blocking solution $(10 \mathrm{mg} / \mathrm{mL})$ at $37^{\circ} \mathrm{C}$ for $1 \mathrm{~h}$. Then, cells were incubated with each immunoconjugate $(10 \mu \mathrm{g} / \mathrm{mL})$ at RT for $1 \mathrm{~h}$, followed by incubation with an AlexaFluor488-conjugated anti-human secondary antibody (1:200; $\left(\mathrm{F}\left(\mathrm{ab}^{\prime}\right)_{2}\right.$-goat anti-human IgG $(\mathrm{H}+\mathrm{L})$ Cross-Adsorbed, Thermo Fisher Scientific) at RT in the dark for $1 \mathrm{~h}$. Cells were then washed three times and suspended in PBS for analysis using a Gallios cytometer (Beckman Coulter, Villepinte, France).

\subsection{RIC Stability}

A $100 \mu \mathrm{L}$ aliquot of each radiopharmaceutical was added to $900 \mu \mathrm{L}$ of culture medium or human serum. Then, samples were incubated on a shaker at $37^{\circ} \mathrm{C}$. At the desired time points, the radiopharmaceutical stability was evaluated by iTLC using a $50 \mathrm{mM}$ EDTA ( $\mathrm{pH}$ 5.5) solution as eluant. The retention factor (Rf) of the RIC was 0 and that of free indium was 1. Each experiment was repeated twice and the percentage of radionuclides bound to proteins for each RIC was calculated after measurement with a $\gamma$-ray counter. 

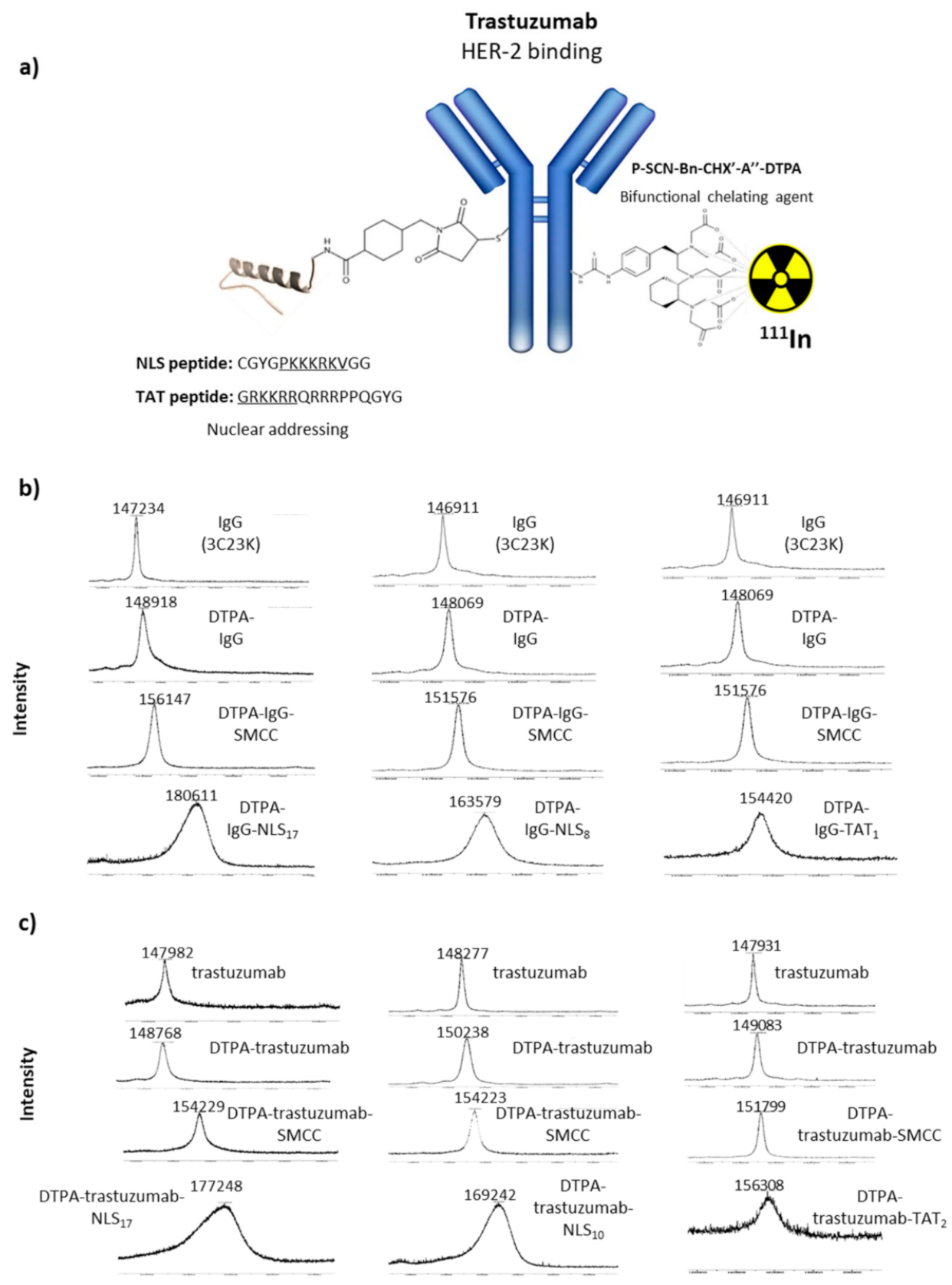

Figure 1. MALDI-TOF analysis of immunoconjugates. (a) Schematic representation of the DTPAmAb-sulphoSMCC-TAT and DTPA-mAb-sulphoSMCC-NLS immunoconjugates. (b) MALDI-TOF analysis of IgG, DTPA-IgG, DTPA-IgG-sulpho-SMCC and DTPA-IgG-sulpho-SMCC-TAT, and DTPAIgG-sulphoSMCC-NLS immunoconjugates. (c) MALDI-TOF analysis of trastuzumab, DTPAtrastuzumab, DTPA-trastuzumab-sulpho-SMCC and DTPA-trastuzumab-sulpho-SMCC-TAT, and DTPA-trastuzumab-sulphoSMCC-NLS immunoconjugates.

\subsection{Determination of the RIC Immunoreactive Fraction}

RIC immunoreactive fractions were assessed using a bead-based assay method described by Sharma et al. [33]. Briefly, $20 \mu \mathrm{L}$ of the magnetic HisPur Ni-NTA bead slurry (Thermo Scientific) was incubated with $1 \mu \mathrm{g}$ His-Tag human recombinant HER2 protein (Sino Biological). Coated beads were then incubated with $1 \mathrm{ng}$ of RIC in the presence (or not) of unlabelled trastuzumab (blocked condition; $\times 1000$-fold excess) on a shaker at RT for $30 \mathrm{~min}$. Beads were isolated, and the supernatant containing unbound RICs was collected. Next, beads were washed twice with PBS-Tween $(0.05 \%)$ to remove non-specifically 
bound RICs. Finally, the activity in each fraction (beads alone, supernatant, and wash) was measured using a $\gamma$-ray counter, and the immunoreactive fractions were calculated.

\subsection{Clonogenic Assays}

Cell survival after incubation with ${ }^{111}$ In-RICs or unlabelled immunoconjugates was assessed using a standard clonogenic assay. Briefly, a defined number of cells, from 100 to 800 , were plated in 6-well plates in $2 \mathrm{~mL}$ of fresh culture medium. The next day, cells were incubated with an increasing amount of activities of ${ }^{111} \mathrm{In}-\mathrm{RICs}(0$ to $4 \mathrm{MBq} / \mathrm{mL}$ ) or $10.8 \mu \mathrm{g} / \mathrm{mL}$ unlabelled immunoconjugates at $37{ }^{\circ} \mathrm{C} / 5 \% \mathrm{CO}_{2}$ for $48 \mathrm{~h}$, followed by three washes with $2 \mathrm{~mL}$ PBS and the addition of fresh medium $(2 \mathrm{~mL})$. Then, cells were cultured for 12 days, and colonies were fixed (acetic acid:methanol [1:3]) and stained with Giemsa diluted in $\mathrm{H}_{2} \mathrm{O}$ (1:5; Sigma-Aldrich, Saint-Quentin Fallavier, France). Colonies were manually counted, and the surviving fraction was calculated. All experiments were repeated at least three times in triplicate for each condition.

\subsection{In Vitro Measurement of DNA Damage}

Cells were seeded on coverslips in 6-well plates. The next day, cells were incubated with $4 \mathrm{MBq} / \mathrm{mL}$ of HER2-specific or irrelevant ${ }^{111} \mathrm{In}$-RICs for $48 \mathrm{~h}$. After RIC removal, cells were washed with PBS three times and fixed with $4 \%(v / v)$ paraformaldehyde in PBS at RT for $15 \mathrm{~min}$, permeabilised with Triton X-100 (0.5\% in PBS) at RT for $15 \mathrm{~min}$, and blocked with PBS/BSA blocking solution $(10 \mathrm{mg} / \mathrm{mL})$ at $37^{\circ} \mathrm{C}$ for $1 \mathrm{~h}$. Next, cells were incubated with an anti-phosphorylated histone $\mathrm{H} 2 \mathrm{AX}(\gamma \mathrm{H} 2 \mathrm{AX})$ antibody diluted in PBS (1:200; 05-636, Sigma Aldrich, Saint-Quentin Fallavier, France) at $37^{\circ} \mathrm{C}$ for $1 \mathrm{~h}$, followed by washing and incubation with a goat anti-mouse IgG $(\mathrm{H}+\mathrm{L})$ FITC-conjugated antibody diluted in PBS/BSA (1:400; 12-506, Sigma-Aldrich, Saint-Quentin Fallavier, France) at $37^{\circ} \mathrm{C}$ for $1 \mathrm{~h}$. Finally, cells were washed with PBS/Tween-20 (0.1\%) and then with PBS (three times/each). Coverslips were mounted on slides with Vectashield antifade mounting medium and DAPI (Vector laboratories, Les Ulis, France) and imaged using a $\times 63$ or $\times 40$ objective on a Leica fluorescence inverted microscope (Leica Microsystems, Wetzlar, Germany), as described previously [15].

\subsection{Radioactivity Uptake and Cell Fractionation}

To isolate nuclei, the chaotropic method described by Pouget et al. [34] was used. Briefly, $1 \times 10^{6}$ cells grown in T25 flasks overnight were incubated with $0.1 \mathrm{MBq} / \mathrm{mL}(3 \mathrm{~mL})$ ${ }^{111}$ In-RICs for $48 \mathrm{~h}$. At various time-points (1, 2, 3, and 6 days), cells were trypsinised and rinsed with PBS three times to remove unbound RICs. The activity of isolated whole cells was determined with a $\gamma$-ray counter (Hidex Automatic gamma counter, Villebonsur-Yvette, France). Next, cells were resuspended in $1 \mathrm{~mL}$ lysis buffer ( $320 \mathrm{mM}$ sucrose, $5 \mathrm{mM} \mathrm{MgCl}_{2}, 10 \mathrm{mM}$ Tris- $\mathrm{HCl}, 0.1 \mathrm{mM}$ deferoxamine, and 1\% Triton X-100 in $\mathrm{H}_{2} \mathrm{O}$ ) and centrifuged at $1500 \times g$ for $10 \mathrm{~min}$. The supernatant (cytoplasm + membrane) was collected. The pellet was again resuspended in $1 \mathrm{~mL}$ lysis buffer, centrifuged at $1500 \times g$ for $10 \mathrm{~min}$, and the supernatant was collected. The pellet (cell nuclei) was rinsed with $1 \mathrm{~mL}$ PBS three times to remove all traces of cytoplasm or membrane. Finally, the activity present in both fractions (nuclei and cytoplasm + membrane) was measured using a $\gamma$-ray counter. The cumulative number of decays (Bq.s) per cell over 6 days was then calculated as well as the cumulative number of decays (Bq.s) per fraction (nucleus and cytoplasm + membrane).

\subsection{Evaluation of Nuclear Fraction Contamination by Western Blotting}

Nuclei were rinsed twice with PBS and lysed in RIPA buffer (Santa Cruz; Santa Cruz, CA, USA) at $4{ }^{\circ} \mathrm{C}$ for $30 \mathrm{~min}$. The total protein concentration in the nuclear fraction was determined using the BCA Protein Assay Reagent (BCA Assay Kit, Thermo Fisher scientific, Illkirch, France). Then, $6 \mu \mathrm{g}$ of nuclear proteins were separated by SDS-PAGE (12\% polyacrylamide gel) and electrotransferred onto nitrocellulose membranes (Bio-Rad, Grabels, France). Membranes were incubated with anti- $\alpha$-tubulin (11H10) $(1 / 1000$; Cell Signaling 
Technology, Leiden, The Netherlands) and anti-phosphorylated histone 3 (Ser10) antibodies (1/1000; Cell Signaling Technology, Leiden, The Netherlands) diluted in Tris-buffered saline/BSA (5\%). A horseradish peroxidase-conjugated anti-rabbit IgG (Cell Signaling Technology, Danvers, MA, USA) was used as a secondary antibody. Proteins were revealed using an enhanced chemiluminescence system according to the manufacturer's instructions (Clarity, Bio-Rad, Marnes-La-Coquette, France). Protein expression was imaged with a PXi analyser (Ozyme, St Quentin en Yvelines, France).

\subsection{Immunofluorescence Analysis of the Immunoconjugate Subcellular Localisation}

As described in Section 2.8, cells were plated on coverslips in 6-well plates, and, the day after, they were incubated with different unlabelled immunoconjugates for $48 \mathrm{~h}$. Then, cells were fixed and permeabilised (see Section 2.8). After blocking with PBS/BSA, an AlexaFluor-488-conjugated anti-human secondary antibody $\left(1: 200 ;\left(\mathrm{F}\left(\mathrm{ab}^{\prime}\right)_{2}\right.\right.$-goat antihuman IgG (H+L) Cross-Adsorbed, Thermo Fisher Scientific) was added at $37^{\circ} \mathrm{C}$ in the dark for $1 \mathrm{~h}$. Coverslips were then mounted with Vectashield with DAPI (see Section 2.8) and imaged using a $\times 63$ or $\times 40$ objective and a Leica fluorescence inverted microscope.

\subsection{Energy Deposition Calculations}

The energy deposition of Auger electrons, CEs, gamma- and X-rays in spheres was evaluated using the PENELOPE code system [35] that simulates the interactions of radiations as they pass through the medium, in this case water. The detailed energy spectra of the radiations were generated with the BrIccEmis [36,37] code and typically using 5 million decay events. All simulations were done using the Monte Carlo approach.

\subsection{Statistical Analysis}

Data were analysed using GraphPad Prism version 8.4.3 (686). Data were described using means and standard deviation (SD). For gamma-H2AX, data were described using means and the standard error of the mean (SEM). Data were compared using the Student's $t$ test. A $p$ value $<0.05$ was considered significant. The Bliss independence model was used to determine the percentage of specific irradiation. In this method, the global efficacy of $\left[{ }^{111} \mathrm{In}\right]$ In-trastuzumab was dissociated in specific and non-specific efficacy using the following formula, wherein the non-specific efficacy was determined as [ $\left.{ }^{111} \mathrm{In}\right] \operatorname{In}-\operatorname{Ig} \mathrm{G}$ efficacy:

Efficacy $_{[111 \mathrm{In}] \mathrm{In}-\text { trastuzumab }}=$ Specific efficacy + Non specific efficacy $-($ Specific efficacy $\times$ Non specific efficacy $)$

\section{Results}

\subsection{Characterisation of Immunoconjugates and Radiolabelling}

After conjugation with a 15-fold molar excess of p-SCN-Bn-CHX-A"'-DTPA, $2 \pm 1$ DTPA per $\mathrm{mAb}$ were obtained, on average, as confirmed by MALDI-TOF analysis (Figure 1b,c). Subsequent bioconjugation with 50-fold molar excess of the reticulating agent sulphoSMCC and 60-fold molar excess of NLS peptides resulted in a mean of 17-22 NLS peptides per $\mathrm{mAb}$. These immunoconjugates will be referred to as trastuzumab-NLS $17-22$. This number decreased to 5-10 NLS peptides per mAb when a 25-fold molar excess of sulphoSMCC or a 40-fold molar excess of NLS peptides were used. These immunoconjugates will be referred to as trastuzumab-NLS $5-10$. Concerning the functionalisation with TAT peptides, $2 \pm 1$ TAT peptides/mAb were obtained after conjugation with 50-fold molar excess of sulpho-SMCC followed by 60 -fold molar excess of TAT peptides. These immunoconjugates will be referred to as trastuzumab-TAT $1-3$.

The in vitro stability of RICs was assessed by incubation in cell-culture medium and human serum at $37^{\circ} \mathrm{C}$. Results showed excellent stability with percentages of ${ }^{111}$ In bound to protein $>82 \%$ over $72 \mathrm{~h}$ (Figure $2 \mathrm{a}$ ). 
a)

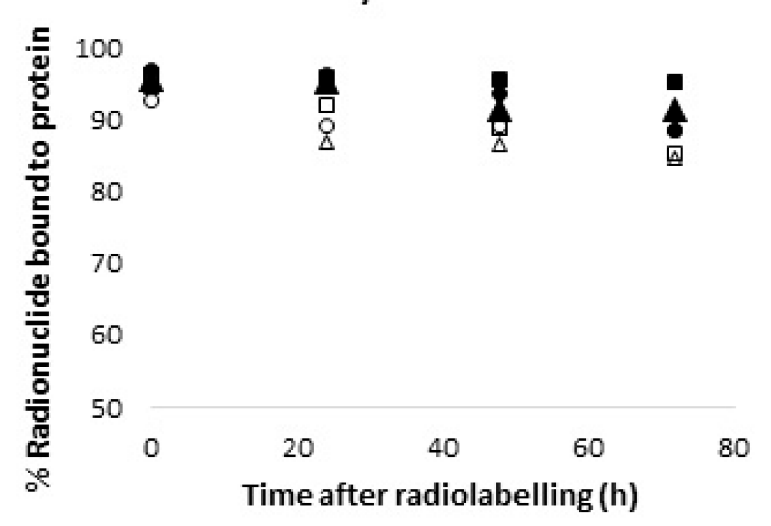

- [111/n] In-trastuzumab

$\square[111 \ln ] \ln -\lg G$

$\Delta[111 \| n]$ In-trastuzumab-NLS 5-10 $\Delta$ [111/n] In-lgG-NLS 5-10

- [111/n] In-trastuzumab-TAT 1-3 o[111/n] In-IgG-TAT 1-3
Stability in human serum

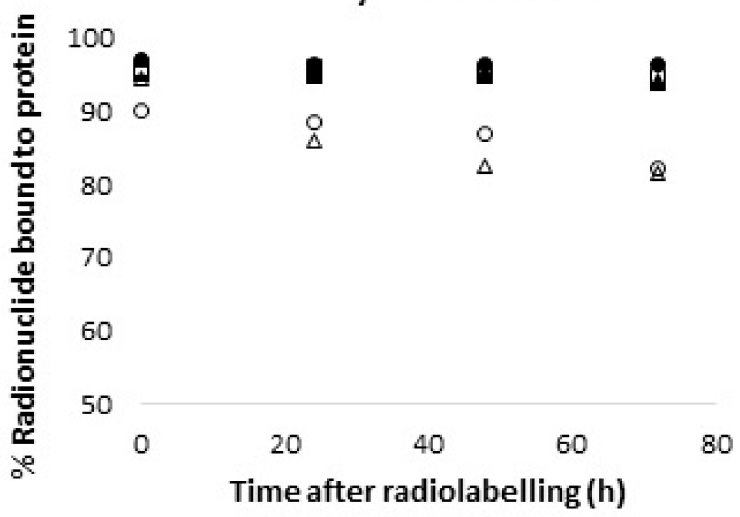

- [111/n] ln-trastuzumab $\quad \square[111 \ln ] \ln -\lg G$

$\Delta$ [111ln] In-trastuzumab-NLS 5-10 $\Delta$ [111ln] In- IgG-NLS 5-10

- [111 In] In-trastuzumab-TAT 1-3 o[111ln] In- IgG-TAT 1-3

b)
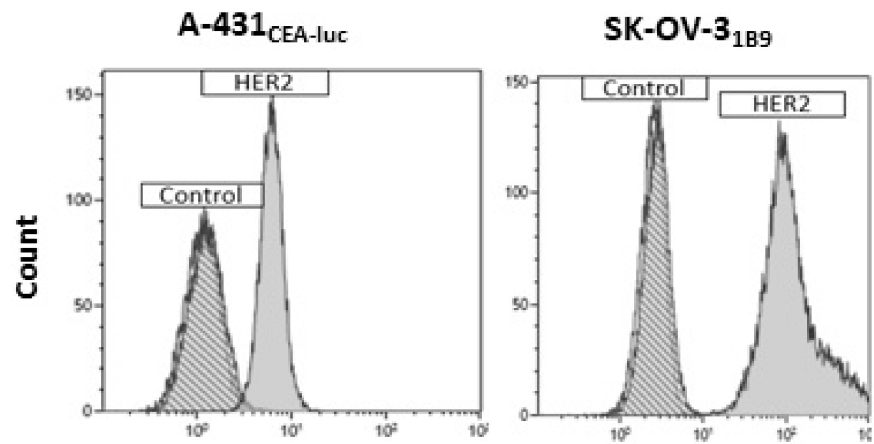

Fluorescence intensity
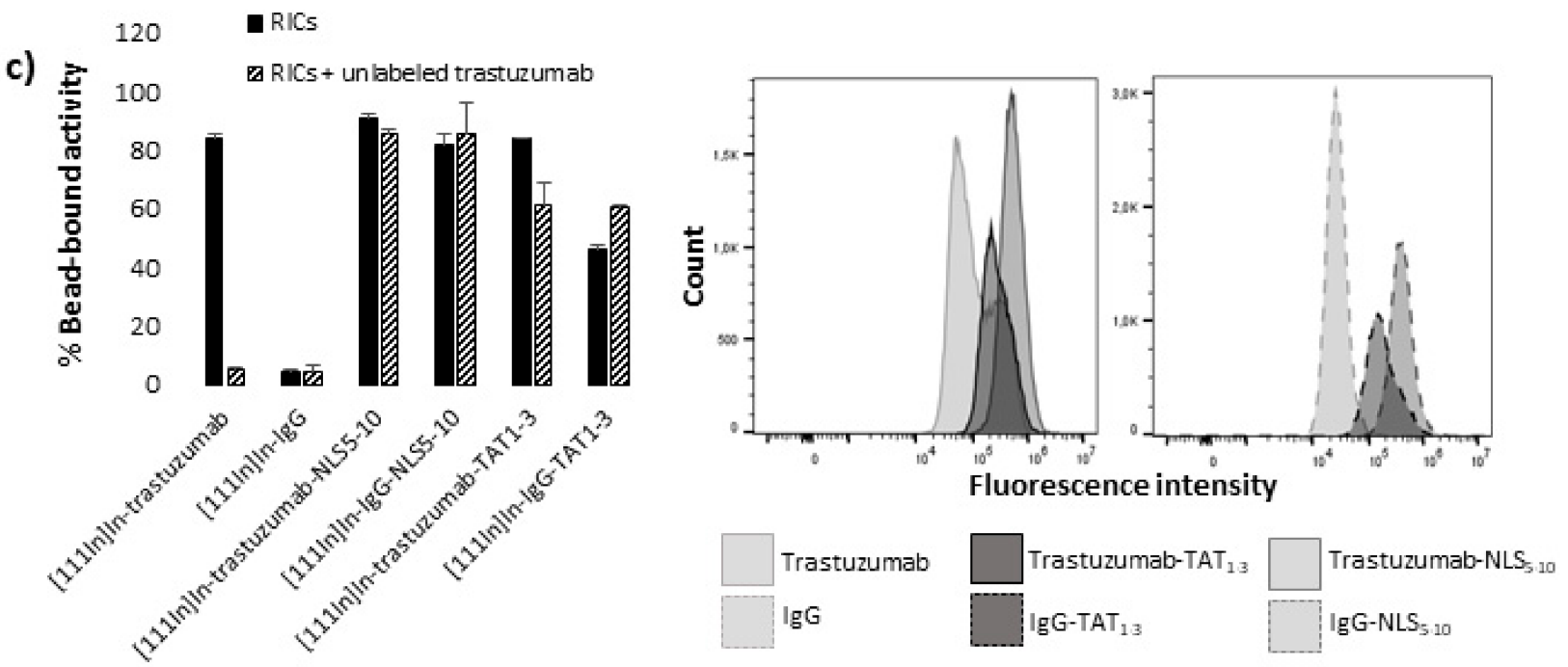

Figure 2. Stability and immunoreactivity of immunoconjugates, HER2 expression. (a) In vitro stability of radioimmunoconjugates. (b) HER-2 expression on A-431 $1_{\mathrm{CEA}-\mathrm{luc}}$ and SK-OV-3 ${ }_{1 \mathrm{~B} 9}$ cells evaluated by flow cytometry. (c) Immunoreactivity assessment using HER2-coated beads (left panel). Flow cytometry assessment of cell binding using a secondary FITClabelled anti-human IgG antibody (right panel). 
Flow cytometry analysis confirmed that HER-2 expression was higher in SK-OV$3_{1 \text { B9 }}$ cells (G-mean: $\times 116$ compared to control) than in A-431 $1_{\text {CEA-luc }}$ cells (G-mean: $\times 4.93$ compared to control) (Figure $2 b$ ). Immunoreactivity assay confirmed that the binding of NLS- or TAT-immunoconjugates was predominantly non-specific because [ $\left.{ }^{111} \mathrm{In}\right] \mathrm{In}-\mathrm{IgG}$ NLS $_{5-10}$ and [ $\left.{ }^{111} \mathrm{In}\right] \mathrm{In}-\mathrm{IgG}-\mathrm{TAT}_{1-3}$ bound to HER2-coated beads. Moreover, the binding of $\left[{ }^{111} \mathrm{In}\right]$ In-trastuzumab-NLS 5 -10 and $\left[{ }^{111} \mathrm{In}\right] \mathrm{In}$-trastuzumab-TAT ${ }_{1-3}$ was not strongly blocked in the presence of a large excess of unlabelled trastuzumab compared with [ ${ }^{111} \mathrm{In}$ ]Intrastuzumab (Figure 2c, left panel). Flow cytometry analysis of the immunoconjugate cell binding also showed that trastuzumab functionalisation with $\mathrm{NLS}_{5-10}$ or $\mathrm{TAT}_{1-3}$ peptides resulted in an increase of the fluorescence signal (G-mean: 104,042, 506,000, and 265,795 for trastuzumab, trastuzumab-NLS ${ }_{5-10}$, and trastuzumab-TAT $1-3$, respectively), indicating higher cell binding. However, this effect was predominantly non-specific because it was observed also after functionalisation of the non-specific IgG mAb (Figure 2c, right panel).

\subsection{Functionalisation with $\mathrm{TAT}_{1-3}$ Peptides Is Associated with a Moderate, Non-Specific Cytotoxicity Increase}

Incubation of A-431 $1_{\text {CEA-luc }}$ and SK-OV-3 ${ }_{1 \mathrm{~B} 9}$ cells with $10.8 \mu \mathrm{g}$ unlabelled $\mathrm{mAb}, \mathrm{mAb}$ $\mathrm{NLS}_{5-10}$, or $\mathrm{mAb}^{-\mathrm{TAT}_{1-3}}$ (corresponding to the $\mathrm{mAb}$ mass added in the ${ }^{111}$ In-treated $4 \mathrm{MBq} / \mathrm{mL}$ groups) for $48 \mathrm{~h}$ did not have any effect on clonogenic survival compared with untreated cells (Supplementary Figure S1). Conversely, the clonogenic survival of cells exposed to increasing activities $(0-4 \mathrm{MBq} / \mathrm{mL})$ of $\left[{ }^{111} \mathrm{In}\right] \mathrm{In}$-trastuzumab or $\left[{ }^{111} \mathrm{In}\right] \mathrm{In}-\mathrm{IgG}$ was significantly decreased (Figure 3). At $4 \mathrm{MBq} / \mathrm{mL}$, survival was $54 \pm 4 \%(p<0.0001)$ and $64 \pm 4 \%(p<0.0001)$ after incubation with [ $\left.{ }^{111} \mathrm{In}\right]$ In-trastuzumab, and $71 \pm 3 \%(p<0.0001)$ and $75 \pm 2 \%(p<0.0001)$ after incubation with $\left[{ }^{111} \mathrm{In}\right] \mathrm{In}-\mathrm{IgG}$, in A-431 $\mathrm{CEA}-\mathrm{luc}$ and SK-OV$3_{1 \mathrm{~B} 9}$ cells, respectively. This indicates that non-specific ${ }^{111} \mathrm{In}$ irradiation contributes to $25-29 \%$ of cell death, while specific irradiation kills between 15 and $24 \%$ more cells (using the Bliss independence model).

Energy deposit calculations indicated that ${ }^{111}$ In emitted 7.19 Auger electrons per decay with a mean energy of $0.94 \mathrm{keV}$ released over a maximal range of about $12 \mu \mathrm{m}$. It also emitted 0.16 CEs per decay, which corresponded to a mean energy of $176 \mathrm{keV}$ (maximum range of $573 \mu \mathrm{m}$ ). The energy deposition in a sphere of $20 \mu \mathrm{m}$, which corresponds roughly to the diameter of a SK-OV-3 1 B9 cell, was about $5.97 \mathrm{keV}$. This increased up to $37 \mathrm{keV}$ for a sphere of $100 \mu \mathrm{m}$ in diameter. ${ }^{111}$ In also emitted 1.85 energetic photons of 150.8 and $245.3 \mathrm{keV}$ per decay, depositing only about $0.114 \mathrm{keV}$ in a $100 \mu \mathrm{m}$ diameter sphere that did not contribute to cell killing in vitro. Therefore non-specific cytotoxicity could be due to CEs co-emitted by ${ }^{111}$ In.

Functionalisation with TAT peptides ([ $\left.{ }^{111} \mathrm{In}\right]$ In-trastuzumab-TAT $1-3 ;$ Figure $\left.1 \mathrm{a}\right)$ did not improve cytotoxicity in A-431 $1_{\text {CEA-luc }}$ cells $(p=0.4$; Figure $3 a)$. In SK-OV-3 1 B9 cells, it increased cytotoxicity only at the highest tested volumic activity $(4 \mathrm{MBq} / \mathrm{mL})$ compared with [ $\left.{ }^{111} \mathrm{In}\right]$ In-trastuzumab (44 $\pm 3 \%$ vs. $64 \pm 4 \%, p=0.005$; Figure $\left.3 a\right)$. At this volumic activity, $\left[{ }^{111} \mathrm{In}\right] \mathrm{In}-\mathrm{IgG}_{-} \mathrm{TAT}_{1-3}$ showed similar cytotoxicity $(29 \pm 0.4 \%, p=0.1)$. A similar trend for $\left[{ }^{111} \mathrm{In}\right] \mathrm{In}-\mathrm{IgG}_{-} \mathrm{TAT}_{1-3}$ was observed at all tested volumic activities, indicating that the functionalisation of the trastuzumab-DTPA conjugate with TAT peptides is associated with loss of antigen specificity. 
a)

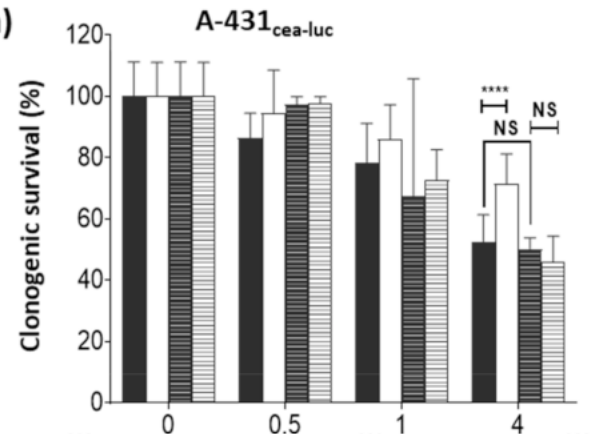

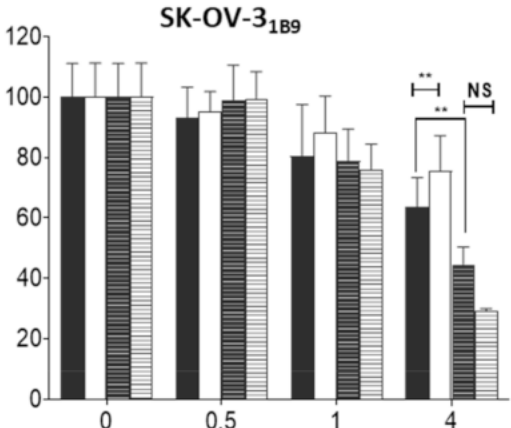

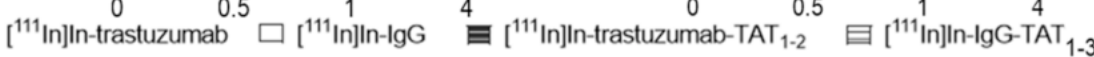
Volumic activity $(\mathrm{MBq} / \mathrm{mL})$

b)

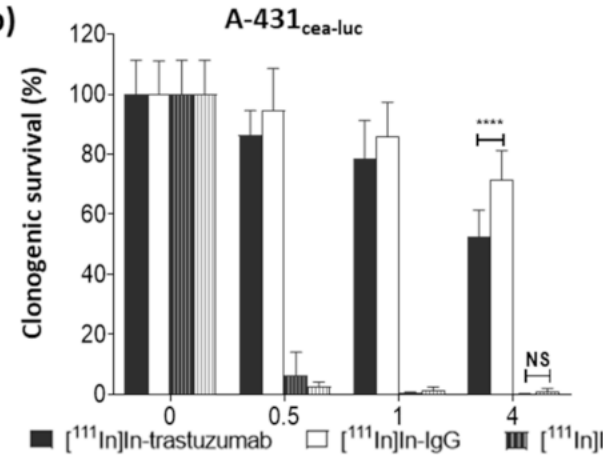

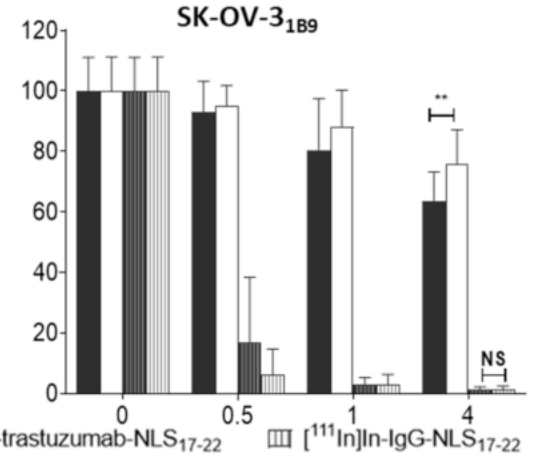

Volumic activity (MBq/mL) c)

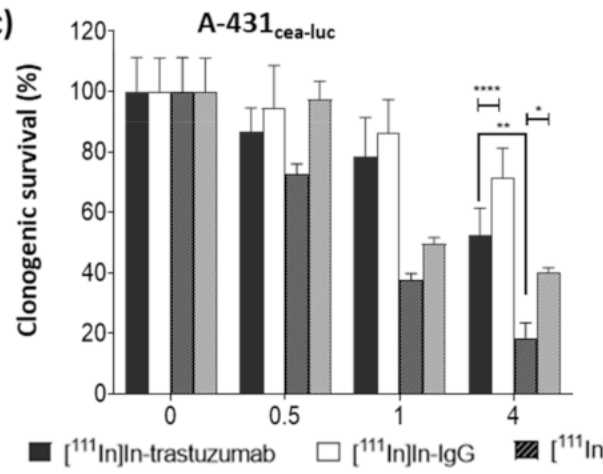

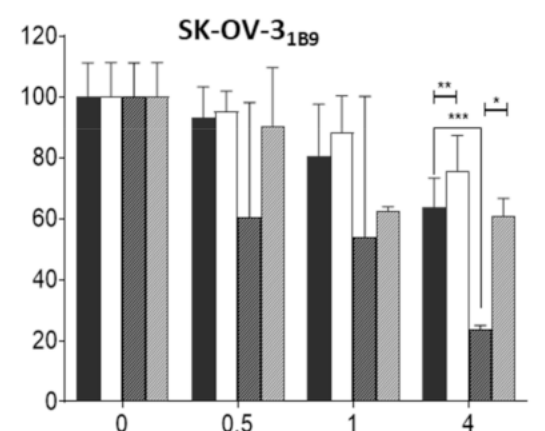

Volumic activity $(\mathrm{MBq} / \mathrm{mL})$

Figure 3. In vitro clonogenic cell death of radioimmunoconjugates. Clonogenic survival was assessed in A-431 $1_{\text {CEA-luc }}$ and SK-OV-3 1 B9 cells 12 days after a $48 \mathrm{~h}$ exposure to [ ${ }^{111} \mathrm{In}$ ]In-trastuzumab or $\left[{ }^{111} \mathrm{In}\right] \mathrm{In}-\mathrm{IgG}$, and (a) $\left[{ }^{111} \mathrm{In}\right] \mathrm{In}$-trastuzumab-TAT $1-3$ or $\left[{ }^{111} \mathrm{In}\right] \mathrm{In}-\mathrm{IgG}_{\mathrm{TAT}}$; ; (b) $\left[{ }^{111} \mathrm{In}\right] \mathrm{In}$ trastuzumab-NLS $17-22$ or [ [111 In]In-IgG-NLS $17-22$; (c) [ [111 In]In-trastuzumab-NLS $5-10$, or [ $\left.{ }^{111} \mathrm{In}\right] \mathrm{In}-\mathrm{IgG}$ $\mathrm{NLS}_{5-10}(0-4 \mathrm{MBq} / \mathrm{mL} ; 0-10.8 \mu \mathrm{g} / \mathrm{mL})$. Data are the mean \pm SD. Experiments were performed at least three times in triplicate. ${ }^{*} p \leq 0.05,{ }^{* *} p \leq 0.01,{ }^{* * *} p \leq 0.001,{ }^{* * * *} p \leq 0.0001$.

\subsection{Functionalisation with $\mathrm{NLS}_{17-22}$ Peptides Is Associated with Higher Non-Specific Cytotoxicity}

Then, trastuzumab-DTPA was conjugated to NLS peptides (Figure 1a), and the cytotoxicity of the resulting $\left[{ }^{111} \mathrm{In}\right] \mathrm{In}$-trastuzumab-NLS ${ }_{17-22}$ was assessed. Exposure to $\left[{ }^{111} \mathrm{In}\right] \mathrm{In}-$ trastuzumab-NLS ${ }_{17-22}$ resulted in a marked decrease in cell survival at all tested volumic activities, but, again, a similar trend was observed when using the non-specific [ $\left.{ }^{111} \mathrm{In}\right] \mathrm{In}$ IgG-NLS $17-22$ (Figure 3b)

\subsection{Functionalisation with $N L S_{5-10}$ Is Associated with High and Moderate} Non-Specific Cytotoxicity

On the basis of the hypothesis that the non-specific cytotoxicity of [111 In]In-trastuzumab$\mathrm{NLS}_{17-22}$ could be due to the mAb's high degree of functionalisation with NLS peptides, 
$\left[{ }^{111}\right.$ In]In-trastuzumab-NLS 5 -10 (only 5 to 10 NLS peptides per mAb molecule) was produced (Figure 1a). At $4 \mathrm{MBq} / \mathrm{mL}$, [ $\left.{ }^{111} \mathrm{In}\right]$ In-trastuzumab-NLS ${ }_{5-10}$ significantly decreased cell survival to $18 \pm 3 \%(p=0.001)$ and $23 \pm 0.6 \%(p=0.0003)$, compared with [ $\left.{ }^{111} \mathrm{In}\right] \mathrm{In}$ trastuzumab, in A-431 $1_{\text {CEA-luc }}$ and SK-OV-3 ${ }_{1 \mathrm{~B} 9}$ cells, respectively (Figure 3c). [ ${ }^{111}$ In]InIgG-NLS 5-10 cytotoxic activity was significantly lower than that of [ $\left.{ }^{111} \mathrm{In}\right] \mathrm{In}$-trastuzumabNLS $_{5-10}$ in both cell lines ( $p=0.01$ for A-431 $1_{\text {CEA-luc }}$ and $p=0.02$ for SK-OV-3 ${ }_{1 \mathrm{~B} 9}$ ) and also compared with [ $\left.{ }^{111} \mathrm{In}\right] \mathrm{In}-\mathrm{IgG}-\mathrm{NLS}_{17-22}$. However, [ $\left.{ }^{111} \mathrm{In}\right] \mathrm{In}-\mathrm{IgG}-\mathrm{NLS} \mathrm{S}_{5-10}$ cytotoxic activity remained comparable to that of $\left[{ }^{111} \mathrm{In}\right]$ In-trastuzumab $(p=0.1)$ in A-431 CEA-luc.

\section{5. [ ${ }^{111}$ In]In-Trastuzumab-NLS ${ }_{5-10}$ Is Associated with the Highest Activity Uptake per Cell or Nucleus}

A nucleus-isolation technique was used to determine the activity incorporated into the cell nucleus and the activity remaining in the extranuclear fraction (cell cytoplasm and membrane). As these experiments required high cell numbers and large volumes, the activity of $0.1 \mathrm{MBq} / \mathrm{mL}$ was chosen. Western blot analysis showed that $\alpha$-tubulin (marker of the cytoplasmic fraction) was not or barely detectable, whereas histone H3 (nuclear fraction marker) was strongly expressed in the nuclear fraction of both cell lines (Figure 4a), validating our nucleus-isolation technique $(<4 \%$ contamination from the cytoplasmic fraction).

Then, the nuclear and extranuclear activity curves showed a similar trend in both cell lines, with a progressive increase and maximal uptake values at 24 or $48 \mathrm{~h}$ after RIC addition (Figure 4b). As HER2 receptor expression is higher in SK-OV-3 1 B9 cells (Figure 2b), uptake was approximately one log higher in this cell line with a slower activity decrease at $72 \mathrm{~h}$ (i.e., $24 \mathrm{~h}$ after radioactivity removal) (Figure $4 \mathrm{~b}$ ).

From these curves, the cumulative number of decays $(\tilde{\mathrm{A}})$ occurring in the whole cell $\left(\tilde{\mathrm{A}}_{\text {cellular }}\right)$, in the cytoplasm + membrane $\left(\tilde{\mathrm{A}}_{\text {extranuc }}\right)$, and in the nucleus $\left(\tilde{\mathrm{A}}_{\text {nuclear }}\right)$ over 6 days was determined (Figure $4 \mathrm{c}$ ). In the absence of a specific peptide sequence targeting the cell nucleus, $\tilde{\mathrm{A}}_{\text {nuclear }}$ and $\tilde{\mathrm{A}}_{\text {cellular }}$ for $\left[{ }^{111} \mathrm{In}\right] \mathrm{In}$-trastuzumab were 128 and $898 \mathrm{~Bq} . \mathrm{s}$ in A-431 CEA-luc cells and 10 times higher or more (1503 and 12,704 Bq.s) in SK-OV-3 ${ }_{1 \mathrm{~B} 9}$ cells.

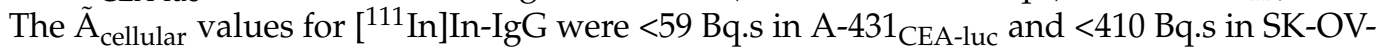
$3_{1 \mathrm{~B} 9}$ cells. The addition of $\mathrm{NLS}_{5-10}$ or $\mathrm{TAT}_{1-3}$ sequences globally improved RIC subcellular uptake (in all compartments) and in both cell lines with a more pronounced effect from $\mathrm{NLS}_{5-10}$ than from TAT $1-3$. HER2 expression level (high versus low) influenced the $\tilde{\mathrm{A}}_{\text {cellular }}$ values, and also the $\tilde{A}_{\text {nuclear }}$ values, which were multiplied by 6.1 in A-431 $1_{\text {CEA-luc }}$ (low expression; trastuzumab versus trastuzumab-NLS ${ }_{5-10}$ ) and only by 2.0 in SK-OV-3 1 B9 (high expression; trastuzumab versus trastuzumab-NLS $\left.{ }_{5-10}\right)$. 
a)

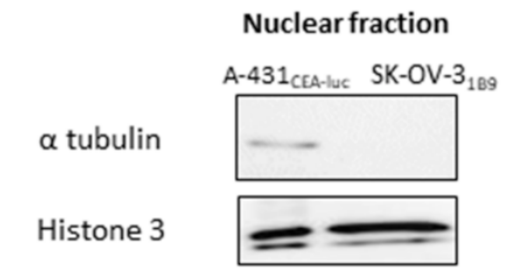

b)
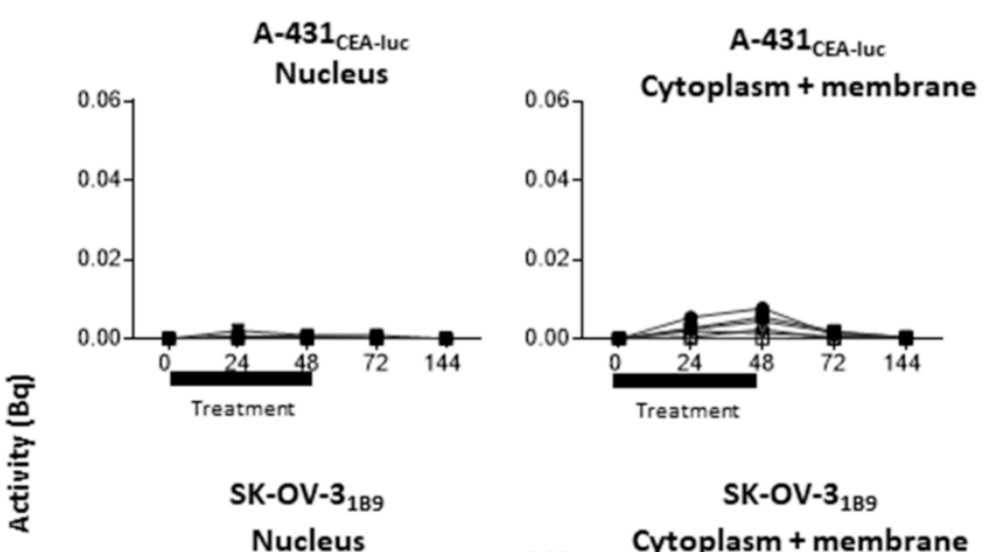

- [111 In] $\mid$-trastuzumab

口. [1"11 In] In-IgG

V [111In]|n-trastuzumab-NLS 5-10

SK-OV-3 ${ }_{189}$
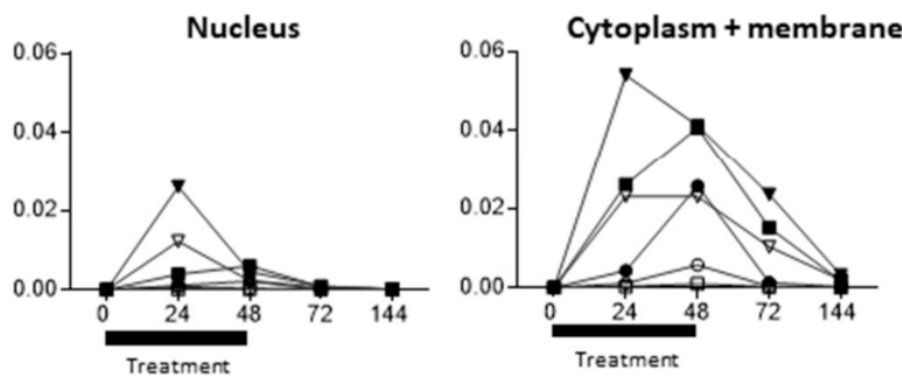

$\nabla\left[\left[^{111} \ln \right] \ln -\lg G-N L S_{5-10}\right.$

- $\left[^{111}\right.$ In]In-trastuzumab-TAT ${ }_{1-3}$

- [ ${ }^{111}$ In] In-IgG-TAT $1-3$
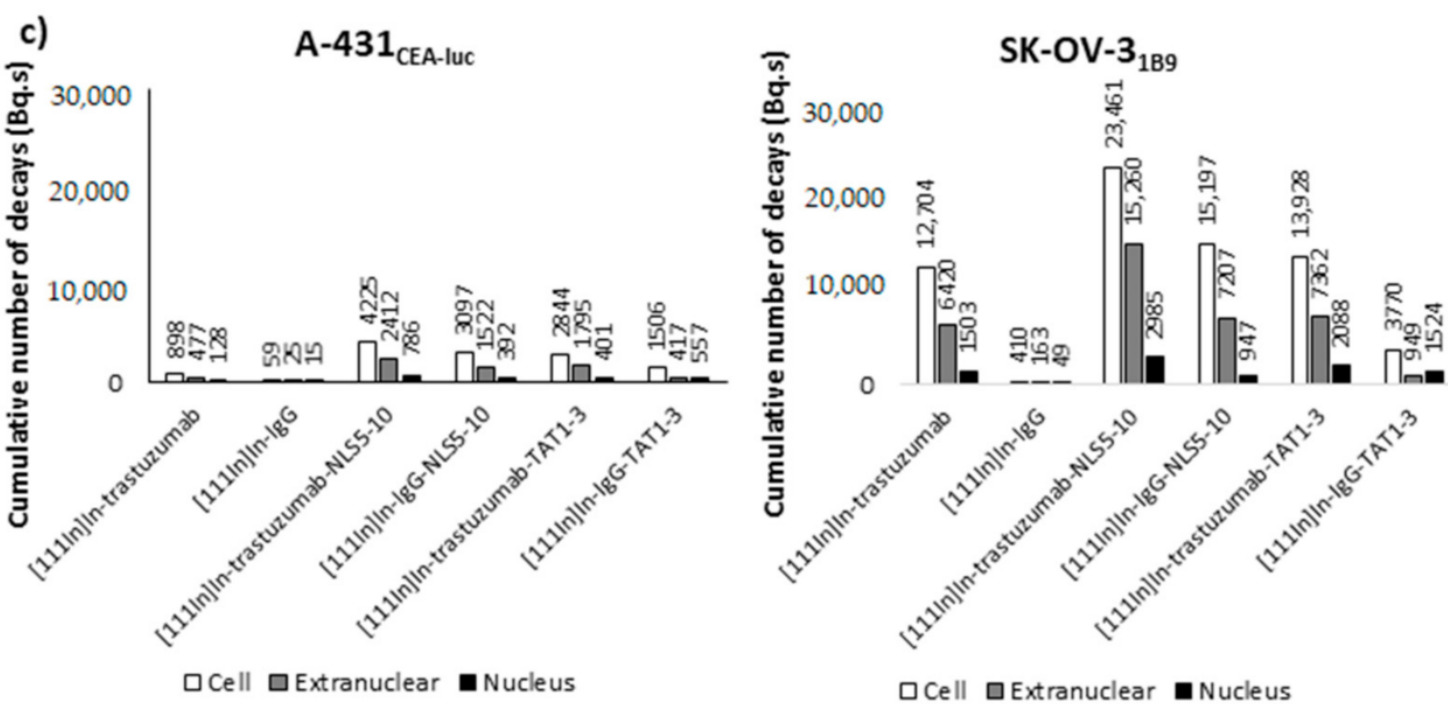

Figure 4. Evaluation of the nuclear and extranuclear uptake of radioactivity (a) Expression of histone 3 and $\alpha$-tubulin was determined in the nuclear fraction by Western blotting to validate the nuclear-fraction isolation technique. (b) Cells were exposed to the indicated ${ }^{111}$ In-radioimmunoconjugates $(0.1 \mathrm{MBq} / \mathrm{mL})$ for $48 \mathrm{~h}$. At different times post-treatment onset (from $24 \mathrm{~h}$ to $144 \mathrm{~h}$ ), cells were counted and fractionated, and activities were measured in whole cells, in the nuclear fraction and in the extranuclear fraction. Using the AUC, (c) the cumulative number of decays per cell or nucleus for the different RICs was calculated in the whole cell $\left(\tilde{\mathrm{A}}_{\text {cellular }}\right)$, in the cytoplasm $\left(\tilde{\mathrm{A}}_{\text {extranuclear }}\right)$, and in the nucleus $\left(\tilde{\mathrm{A}}_{\text {nuclear }}\right)$. 


\subsection{TAT and NLS Peptides Do Not Increase the Percentage of Activity Reaching the Nucleus}

Although, the raw $\tilde{A}_{\text {extranuc }}$ and $\tilde{A}_{\text {nuclear }}$ values increased with the addition of NLS and TAT peptides, the ratio between these values did not highlight any specific increase in nuclear targeting (Figure 5a).

a)
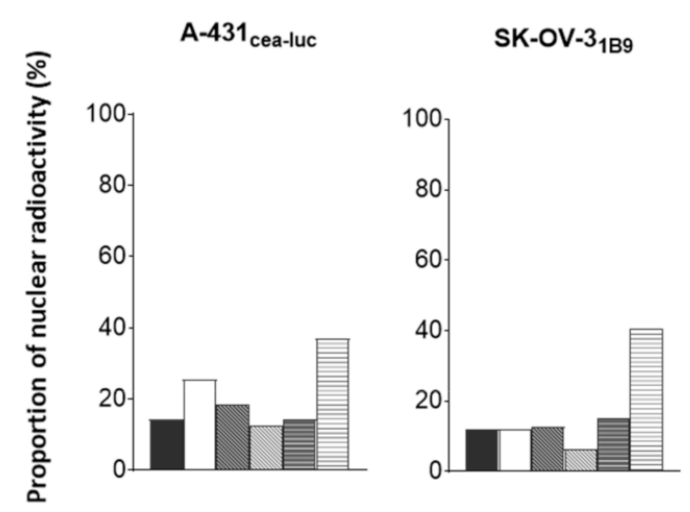

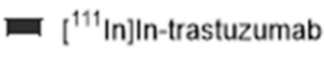

口 $\left[^{111} \ln \right] \ln -\lg G$

DII $\left[{ }^{111} \operatorname{In}\right]$ In-trastuzumab-NLS $S_{5-10}$

b)

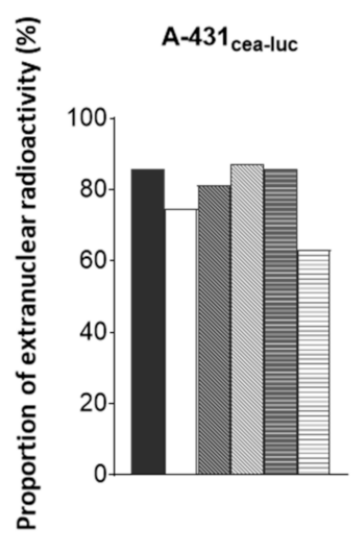

[प्य $\left[{ }^{111} \operatorname{In}\right] \ln -I g G-N L S_{5-10}$

E[ ${ }^{111}$ In] In-trastuzumab-TAT $1-3$

$\square\left[{ }^{111} \ln \right] \ln -\lg \mathrm{G}-\mathrm{TAT}_{1-3}$

Figure 5. Percentage of: (a) nuclear and; (b) extranuclear activity. The percentage of activity in the nuclear and extranuclear fraction was calculated for each RIC based on the cumulative number of decays per cell ( $\tilde{\mathrm{A}}_{\text {nuclear }}$ and $\tilde{\mathrm{A}}_{\text {cellular }}$ ).

The proportion of radioactivity in the nucleus remained between 6 and 18\% for all RICs, indicating that nuclear targeting was not specific. It must be noted that the nuclear proportion of $\left.{ }^{111} \mathrm{In}\right] \mathrm{In}-\mathrm{IgG} \mathrm{TAT}_{1-3}$ was higher $\left(37 \%\right.$ and $40 \%$ in A-431 $1_{\mathrm{CEA}-\mathrm{luc}}$ and SK-OV-31B9 cells, respectively), but this was mainly due to low cellular uptake such that the percentage was increased. The same conclusion can be drawn for [ $\left.{ }^{111} \mathrm{In}\right] \mathrm{In}-\mathrm{IgG}$ in A-431 $1_{\text {CEA-luc }}$ (Figure 5a).

By analogy, for $\left[{ }^{111} \mathrm{In}\right] \mathrm{In}$-trastuzumab-NLS ${ }_{5-10}$, the $\tilde{\mathrm{A}}_{\text {extranuc }}$ value represented $81 \%$ (versus $86 \%$ for $\left[{ }^{111} \mathrm{In}\right]$ In-trastuzumab) of the cumulative number of decays $(\tilde{\mathrm{A}})$ occurring in the whole cell $\left(\tilde{\mathrm{A}}_{\text {cellular }}\right)$ in A-431 $1_{\text {CEA-luc }}$ and $87 \%$ (versus $88 \%$ for [ ${ }^{111} \mathrm{In}$ ]In-trastuzumab) in SK-OV-3 1 B9 cells, indicating that NLS addition improved cellular uptake but not nuclear targeting (Figure 5b).

For [ ${ }^{111} \mathrm{In}$ ]In-trastuzumab-TAT $1-3, \tilde{\mathrm{A}}_{\text {extranuc }}$ represented $86 \%$ in A-431 ${ }_{\text {CEA-luc }}$ (versus $86 \%$ for $\left[{ }^{111} \mathrm{In}\right.$ ]In-trastuzumab) and $85 \%$ in SK-OV- ${ }_{1 \mathrm{~B} 9}$ (versus $88 \%$ for [ ${ }^{111} \mathrm{In}$ ] Intrastuzumab) of all decays. Therefore, as observed for $\mathrm{NLS}_{5-10}$, the addition of $\mathrm{TAT}_{1-3}$ did not significantly improve nuclear targeting but did increase the total cellular uptake. 


\subsection{TAT and NLS Increase the Non-Specific Cellular Uptake}

The addition of $\mathrm{NLS}_{5-10}$ or $\mathrm{TAT}_{1-3}$ resulted in an overall increase of cellular, and subsequently nuclear, uptake of the non-specific IgG RIC (Figures $4 \mathrm{c}$ and 5). Compared with [ $\left.{ }^{111} \mathrm{In}\right] \mathrm{In}-\mathrm{IgG}$, the $\tilde{\mathrm{A}}_{\text {cellular }}$ value for $\left[{ }^{111} \mathrm{In}\right] \mathrm{In}-\mathrm{IgG}-\mathrm{NLS} \mathrm{S}_{5-10}$ was 52 times higher in A$431_{\text {CEA-luc }}$ cells (versus 4.7 times for $\left[{ }^{111} \mathrm{In}\right]$ In-trastuzumab-NLS ${ }_{5-10}$ compared with [ $\left.{ }^{111} \mathrm{In}\right] \mathrm{In}$ trastuzumab) and 37 times in SK-OV-3 $3_{189}$ cells (versus 1.8 times for [ $\left.{ }^{111} \mathrm{In}\right] \mathrm{In}$-trastuzumabNLS $5-10$, compared with [ ${ }^{111}$ In]In-trastuzumab). For [ $\left.{ }^{111} \mathrm{In}\right] \mathrm{In}-\mathrm{IgG}-\mathrm{TAT}_{1-3}$, the $\tilde{\mathrm{A}}_{\text {cellular value }}$ was 26 times higher in A-431 $1_{\text {CEA-luc }}$ cells (versus 3.2 times for [ ${ }^{111}$ In]In-trastuzumab-TAT ${ }_{1-3}$, compared with [111 In]In-trastuzumab) and 9.2 times higher in SK-OV-3 ${ }_{1 \text { B9 }}$ cells (versus 1.1 times for $\left[{ }^{111} \mathrm{In}\right] \mathrm{In}$-trastuzumab-TAT ${ }_{1-3}$, compared with [ $\left.{ }^{111} \mathrm{In}\right] \mathrm{In}$-trastuzumab). The HER2-specific/non-specific $\tilde{\mathrm{A}}_{\text {cellular }}$ ratios for $\mathrm{NLS}_{5-10}$ were 1.4 in A-431 $1_{\text {CEA-luc }}$ and 1.5 in SK-OV-3 ${ }_{1 \text { B9 }}$ cells. The HER2-specific/non-specific $\tilde{A}_{\text {cellular }}$ ratios for $\mathrm{TAT}_{1-3}$ were 1.9 in A-431 CEA-luc and 3.7 in SK-OV-31B9 cells.

\subsection{Immunoconjugates Do Not Localise in the Nucleus}

Although less sensitive than radioactive detection, the localisation of the immunoconjugates was next assessed by immunofluorescence analysis (Figure 6). DTPA-trastuzumab was detected at the cell surface and in the cytoplasm. The amount of foci in the cytoplasm

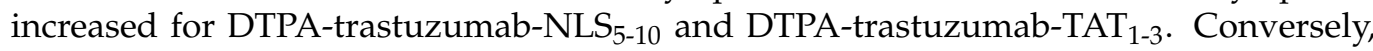
DTPA-IgG mAb was not detected at the cell surface or in the cytoplasm. However, when functionalised with $\mathrm{NLS}_{5-10}$ or $\mathrm{TAT}_{1-3}$, the number of cytosolic DTPA-IgG mAb foci increased. Few foci of NLS- and TAT-functionalised mAbs were detected in the nucleus, but their number was much lower than in the cytoplasm.

\section{9. [111 In]In-Trastuzumab-NLS $5-10$ Induces the Highest Number of $\gamma H 2 A X$ Foci per Nucleus}

To investigate whether DNA double strand breaks (DSBs) induction by the different RICs was correlated with their $\tilde{\mathrm{A}}_{\text {cellular }}$ or $\tilde{\mathrm{A}}_{\text {nuclear }}$ values, $\gamma \mathrm{H} 2 \mathrm{AX}$ focus formation was monitored at various time points in A-431 $1_{\text {CEA-luc }}$ and SK-OV-3 ${ }_{1 B}$ cells by immunofluorescence analysis (Figure 7a,b, left panels). The highest yield of $\gamma \mathrm{H} 2 \mathrm{AX}$ foci (indicative of DNA DSBs) was observed in cells incubated with [ $\left.{ }^{111} \mathrm{In}\right] \mathrm{In}$-trastuzumab-NLS $\mathrm{S}_{5-10}(12.0 \pm 7.0 \mathrm{foci} / \mathrm{cell}$ and $9.9 \pm 2.9$ foci/cell in A-431 $1_{\text {CEA-luc }}$ and SK-OV-3 ${ }_{1 \mathrm{~B} 9}$ cells, respectively). In A-431 CEA-luc cells, it was followed by [ $\left.\left.{ }^{111} \mathrm{In}\right] \mathrm{In}-\mathrm{IgG}-\mathrm{NLS}_{5-10}(5.0 \pm 4.1 \mathrm{foci} / \mathrm{cell}),{ }^{[11} \mathrm{In}\right] \mathrm{In}$-trastuzumab $\left(4.1 \pm 5.9 \mathrm{foci} / \mathrm{cell}\right.$, and [ $\left.{ }^{111} \mathrm{In}\right] \mathrm{In}$-trastuzumab-TAT ${ }_{1-3}(3.5 \pm 5.9 \mathrm{foci} / \mathrm{cell})$. In SK-OV$3_{1 \mathrm{~B} 9}$ cells, it was followed by [ $\left.{ }^{111} \mathrm{In}\right] \mathrm{In}$-trastuzumab-TAT ${ }_{1-3}(7.7 \pm 3.4 \mathrm{foci} /$ cell $),\left[{ }^{111} \mathrm{In}\right] \mathrm{In}$ $-\operatorname{IgG} \mathrm{TAT}_{1-3}\left(5.9 \pm 3.5\right.$ foci/cell), [111 In]In-IgG-NLS $5-10$ (5.3 \pm 2.4 foci/cell), and [ $\left.{ }^{111} \mathrm{In}\right] \mathrm{In}-$ trastuzumab ( $3.3 \pm 2.3$ foci/cell). For comparison, $0.4 \pm 0.7 \mathrm{foci} /$ cell and $2.0 \pm 2.1 \mathrm{foci} / \mathrm{cell}$ were detected in untreated cells and in A-431 ${ }_{\text {CEA-luc }}$ cells incubated with $\left.{ }^{111} \operatorname{In}\right] \operatorname{In}-\operatorname{IgG}$, respectively. The corresponding values were $0.6 \pm 0.6$ foci/cell and $2.6 \pm 2.4$ foci/cell in SK-OV-3 ${ }_{1 \mathrm{~B} 9}$ cells. Then, the cumulative number of $\gamma \mathrm{H} 2 \mathrm{AX}$ foci over $144 \mathrm{~h}$ was calculated and expressed as a function of the $\tilde{\mathrm{A}}_{\text {cellular }}$ or $\tilde{\mathrm{A}}_{\text {nuclear }}$ values (Figure $7 \mathrm{a}, \mathrm{b}$, right panels). Such foci increased with time, and the $r^{2}$ values ranged between 0.43 and 0.75 . Neither $\tilde{\mathrm{A}}_{\text {cellular }}$ nor $\tilde{\mathrm{A}}_{\text {nuclear }}$ appeared to be the best parameter. 


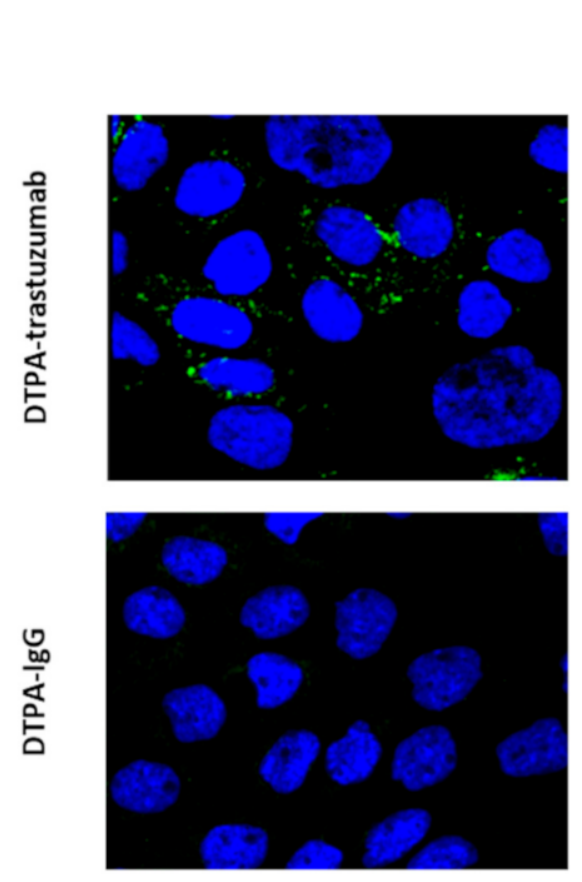

Peptide (-)

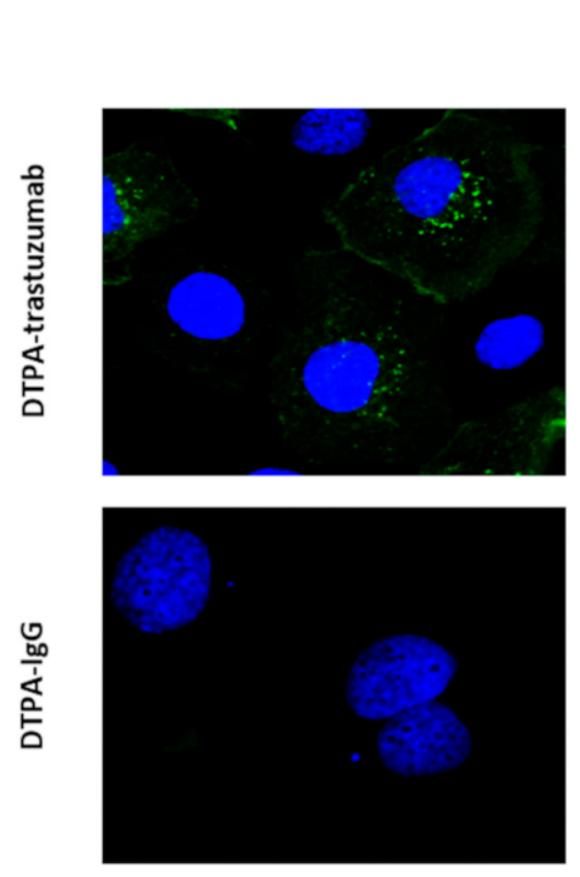

Peptide (-)

\section{A-431 $1_{\text {CEA-luc }}$ \\ $48 \mathrm{~h}$}
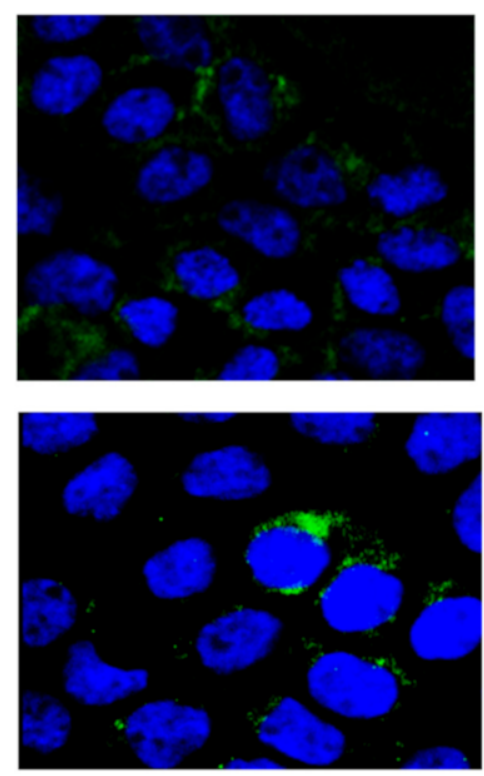

NLS (+)
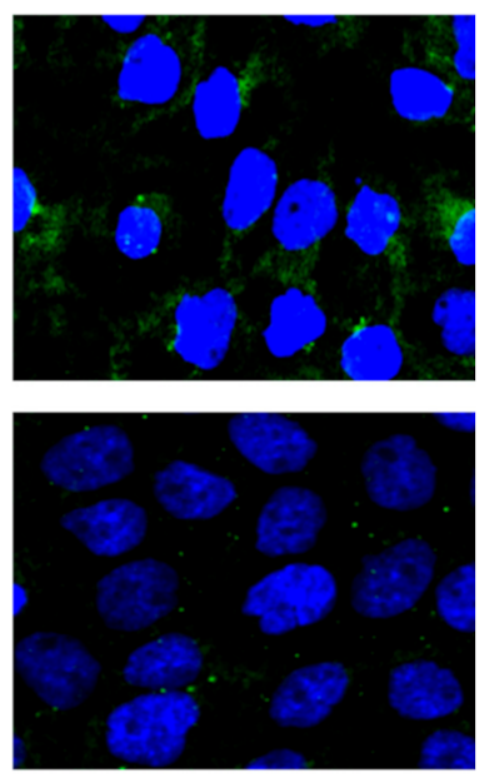

TAT (+)
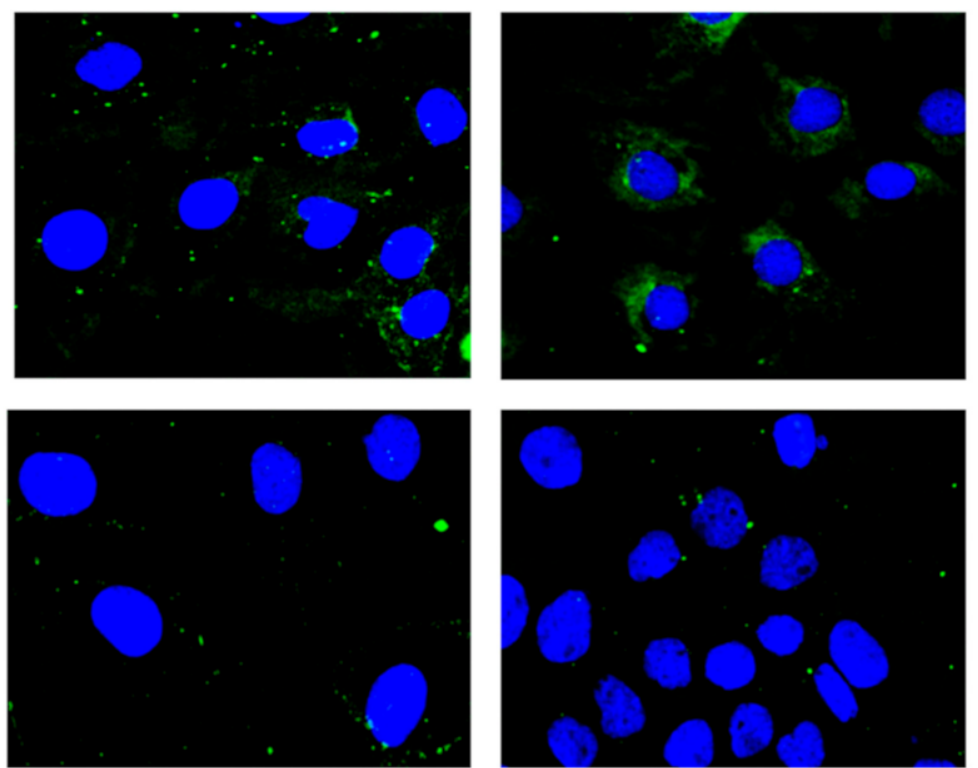

NLS (+)

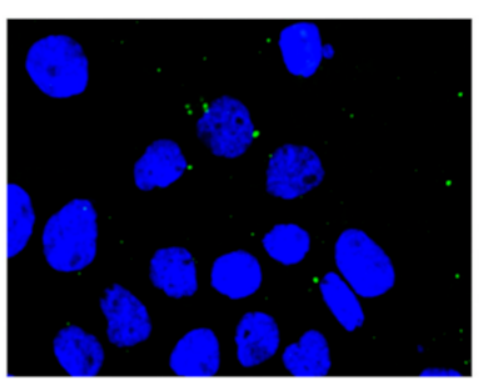

TAT (+)

Figure 6. Immunofluorescence analysis of immunoconjugates $48 \mathrm{~h}$ after incubation onset. A- $431_{\mathrm{CEA}-\mathrm{luc}}$ and SK-OV-3 $1 \mathrm{~B} 9$ cells were incubated with DTPA-trastuzumab, DTPA-trastuzumab-NLS ${ }_{5-10}$, DTPA-trastuzumab-TAT $_{1-3}$, or DTPA-IgG, DTPA-IgG-NLS $5-10$, or DTPA-IgG-TAT $1-3(10.8 \mu \mathrm{g} / \mathrm{mL})$ for $48 \mathrm{~h}$. Cells were fixed, permeabilised and incubated with an AlexaFluor-488-labelled anti-human IgG antibody. Images were acquired using an $\times 63$ or $\times 40$ objective. 

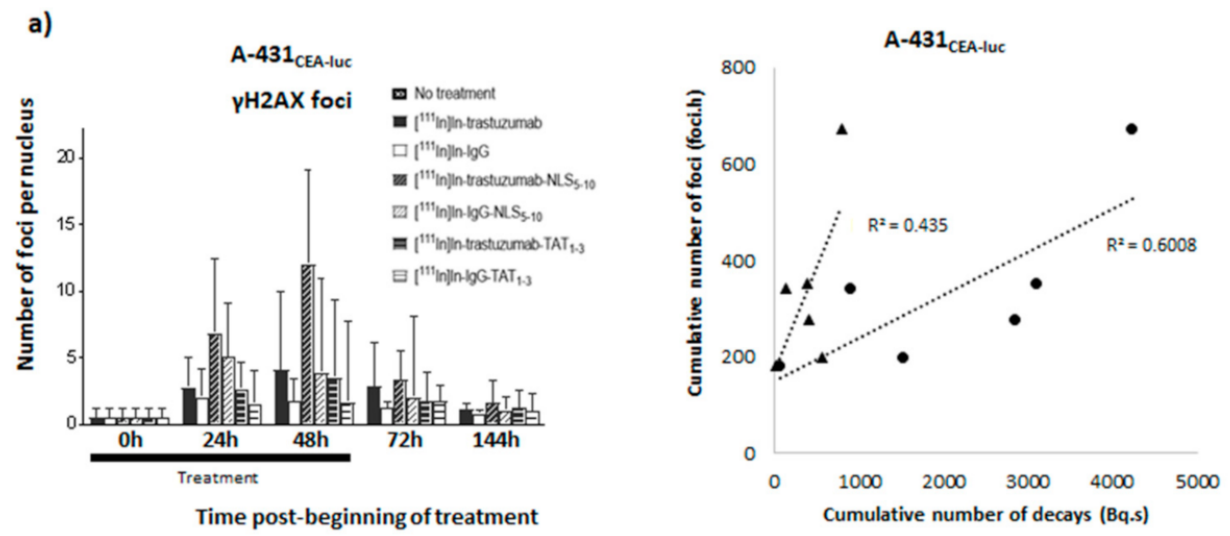

b)
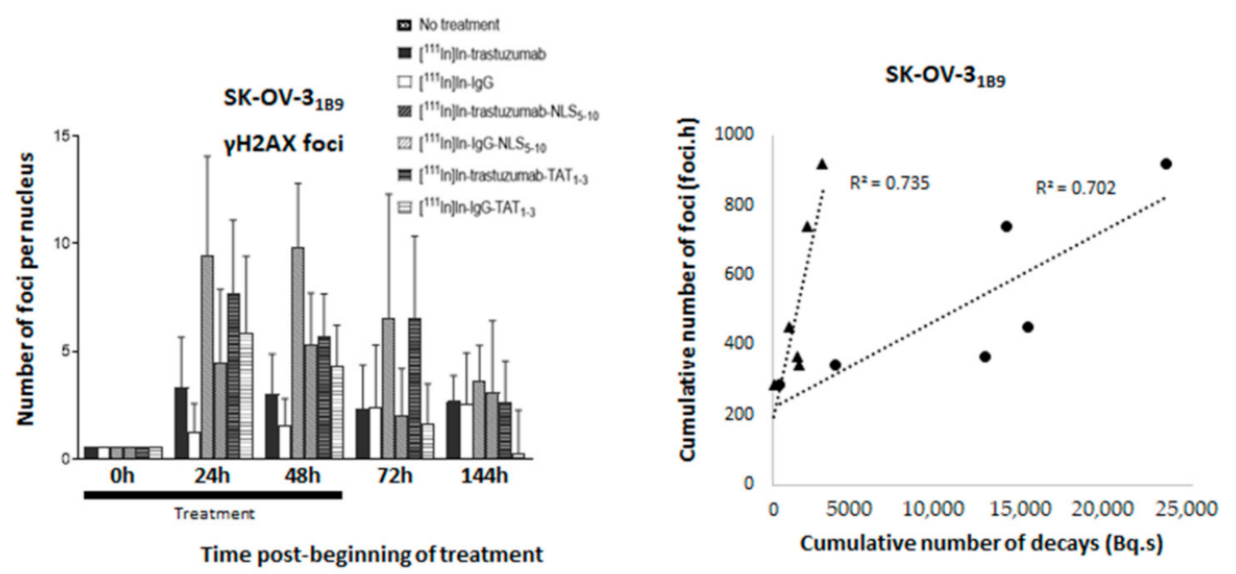

Figure 7. Quantification of $\gamma \mathrm{H} 2 \mathrm{AX}$ foci. $\gamma \mathrm{H} 2 \mathrm{AX}$ foci formation was evaluated at various time points $(24 \mathrm{~h}, 48 \mathrm{~h}, 72 \mathrm{~h}$, and $144 \mathrm{~h}$ ) in (a) A-431 $1_{\mathrm{CEA}-l u c}$ and (b) SK-OV-3 ${ }_{1 \mathrm{~B} 9}$ cells after incubation with $4 \mathrm{MBq} / \mathrm{mL}$ of each RIC. Briefly, cells were fixed, permeabilised, and incubated with an anti- $\gamma \mathrm{H} 2 \mathrm{AX}$ antibody followed, after washing, by a goat anti-mouse IgG FITC conjugate. Images were acquired using a $\times 63$ or $\times 40$ objective, and at least 100 nuclei were analysed per immunoconjugate. Data are the mean \pm SEM. The cumulative number of $\gamma \mathrm{H} 2 \mathrm{AX}$ foci (foci.hour) was expressed as a function of the cumulative number of decays (Bq.s) in the nucleus (triangle markers) and in the whole cell (circle markers).

\section{Discussion}

This study assessed the ability of two highly cationic peptides, the synthetic 13-mer NLS peptide [CGYGPKKKRKVGG] from the simian virus 40 large-T antigen and the synthetic 16-mer TAT peptide [GRKKRRQRRRPPQGYG] from the HIV-1 TAT protein, to drive the ${ }^{111}$ In-anti-HER2 (trastuzumab) RIC into the cell nucleus of two HER2-expressing cancer cell lines, A-431 CEA-luc $\left._{\text {(HER2 }}{ }^{+}\right)$and SK-OV- $3_{1 \mathrm{Bg}}\left(\mathrm{HER}^{++}\right)$. According to the literature, after HER2-mediated internalisation in the cytoplasm, NLS and TAT peptide sequences are recognised by importin- $\alpha$ and importin- $\beta 1$ to form a nuclear-pore-targeting complex [38,39]. This complex facilitates RIC passage through the nuclear pore and their translocation into the nucleus where they will be dissociated to release NLS-/TAT-conjugates [11]. In total, eight RICs were obtained and characterised: $\left[{ }^{111} \mathrm{In}\right] \mathrm{In}$-trastuzumab, [ $\left.{ }^{111} \mathrm{In}\right] \mathrm{In}$ trastuzumab-NLS $5-10,\left[{ }^{111}\right.$ In]In-trastuzumab-NLS ${ }_{17-22}$, $\left[{ }^{111} \mathrm{In}\right]$ In-trastuzumab-TAT ${ }_{1-3}$ as a specific anti-HER2 RIC, and [ [111 In]In-IgG, $\left.\left.{ }^{111} \mathrm{In}\right] \mathrm{In}-\mathrm{IgG}-\mathrm{NLS}_{5-10},{ }^{[111} \mathrm{In}\right] \mathrm{In}-\mathrm{IgG}-\mathrm{NLS}{ }_{17-22}$, and [ $\left.{ }^{111} \mathrm{In}\right] \mathrm{In}-\mathrm{IgG}-\mathrm{TAT}_{1-3}$ as non-specific RICs.

First, functionalisation of trastuzumab with the TAT or NLS peptides slightly increased its cell binding, but this binding was at least predominantly mediated by non-specific mechanisms. Moreover, non-radioactive immunoconjugates showed very low cytotoxicity, 
even when used at the highest concentration $(10.8 \mu \mathrm{g} / \mathrm{mL}$; equivalent to tested volumic activity of $4 \mathrm{MBq} / \mathrm{mL}$ for ${ }^{111} \mathrm{In}$-RIC) (Supplementary Figure S1).

Then, comparison of the different RICs showed that $\left[{ }^{111} \mathrm{In}\right] \operatorname{In}-\mathrm{IgG}$ was significantly less cytotoxic than [ $\left.{ }^{111} \mathrm{In}\right] \mathrm{In}$-trastuzumab, but more than what was reported in previous studies. The origin of ${ }^{111}$ In non-specific cytotoxic effect in vitro could be explained by CE emission. It must be noted that, in several studies showing the absence of non-specific cytotoxicity, clonogenic assays were performed using a protocol different from the one followed in the present study. This previous protocol included two consecutive steps. First, cells were exposed to the radionuclide for several hours before centrifugation and washes. Then, cells were seeded at low concentration for clonogenic assay. It is likely that the first step might have led to the loss of the most damaged cells, and therefore, cell survival was only measured for the most viable cells that had not been eliminated by washing and that could adhere to the flask bottom. Moreover, the non-specific irradiation contribution could be different in vivo, particularly considering that, in the present in vitro experiments, cells were incubated with RICs at high activity for $48 \mathrm{~h}$, a situation that might not reflect the in vivo pharmacokinetics of ${ }^{111}$ In-RICs.

Functionalisation with $\mathrm{TAT}_{1-3}$ peptides did not significantly modify [ $\left.{ }^{111} \mathrm{In}\right] \mathrm{In}$-trastuzumab cytotoxicity in A-431 CEA-luc cells and slightly increased it in SK-OV-3 ${ }_{1 \mathrm{~B} 9}$ cells $(p<0.01)$. The observation that the non-specific $\left[{ }^{111} \mathrm{In}\right] \mathrm{In}-\mathrm{IgG}-\mathrm{TAT}_{1-3}$ was as cytotoxic as $\left[{ }^{111} \mathrm{In}\right] \mathrm{In}$ trastuzumab-TAT ${ }_{1-3}$ indicates that TAT conjugation is associated with the loss of $\mathrm{mAb}$ specificity. The lack of or limited additional cytotoxicity provided by functionalisation with $\mathrm{TAT}_{1-3}$ could be explained by the low increase of activity localisation in the nucleus ( $\tilde{\mathrm{A}}_{\text {nuclear }}$ ) after cell exposure to $\left.{ }^{111} \mathrm{In}\right] \mathrm{In}$-trastuzumab-TAT ${ }_{1-3}$. $\tilde{\mathrm{A}}_{\text {cellular }}$ increase in A-431 $1_{\mathrm{CEA}-\text { luc }}$ and in SK-OV-3 ${ }_{189}$ cells exposed to [111 In]In-trastuzumab-TAT ${ }_{1-3}$ was associated with nonspecificity because it also increased in cells incubated with [111 In]In-IgG- TAT $_{1-3}$. However, the $\tilde{A}_{\text {cellular }}$ increase in SK-OV-3 ${ }_{1 B 9}$ cells was lower than in A-431 $1_{\text {CEA-luc }}$ cells, suggesting that the higher HER2 expression level of this cell line prevented the passive internalisation of the TAT-RIC.

Functionalisation of radiolabelled mAbs with 17 to $22 \mathrm{NLS} / \mathrm{mAb}\left(\mathrm{NLS}_{17-22}\right)$ resulted in a drastic reduction of the surviving fractions for both [ $\left.{ }^{111} \mathrm{In}\right] \mathrm{In}$-trastuzumab-NLS $\mathrm{N}_{17-22}$ and [ $\left.{ }^{111} \mathrm{In}\right] \mathrm{In}-\mathrm{IgG}-\mathrm{NLS}_{17-22}$. Again the addition of NLS peptides was associated with a loss of specificity. Reducing the number of NLS to 5-10 $\left(\mathrm{NLS}_{5-10}\right)$ increased RIC specificity and maintained high cytotoxicity. Nevertheless, even functionalisation with $\mathrm{NLS}_{5-10}$ was associated with non-specific cytotoxicity in A-431 ${ }_{\text {CEA-luc }}$ cells because [ $\left.{ }^{111} \mathrm{In}\right] \mathrm{In}-\mathrm{IgG}-\mathrm{NLS}{ }_{5-10}$ was more cytotoxic than $\left[{ }^{111} \mathrm{In}\right] \mathrm{In}$-trastuzumab $(p=0.001)$, but the difference between the specific and non-specific [ $\left.{ }^{111} \mathrm{In}\right] \mathrm{In}-\mathrm{mAb}-\mathrm{NLS}_{5-10}$ effects was more pronounced than for $\left.{ }^{111} \mathrm{In}\right] \mathrm{In}-\mathrm{mAb}-\mathrm{TAT}_{1-3}$. Cell fractionation experiments showed that functionalisation with $\mathrm{NLS}_{5-10}$ was accompanied by an increase of the $\tilde{\mathrm{A}}_{\text {nuclear }}$ values for both [ $\left.{ }^{111} \mathrm{In}\right] \mathrm{In}$ trastuzumab-NLS $5-10$ and [111 In]In-IgG-NLS 5 -10 in A-431 ${ }_{\text {CEA-luc }}$ cells and, to a lower extent, in SK-OV-3 ${ }_{1 \mathrm{~B} 9}$ cells. Nevertheless, the most striking observation was that the functionalisation of [ $\left.{ }^{111} \mathrm{In}\right] \mathrm{In}$-trastuzumab with $\mathrm{NLS}_{5-10}$ significantly increased $\tilde{\mathrm{A}}_{\text {cellular }}$ in both A-431 $1_{\text {CEA-luc }}(\times 4.7)$ and in SK-OV-3 ${ }_{189}(\times 1.8)$ cells, with a similar trend also for $\left[{ }^{111} \mathrm{In}\right] \mathrm{In}-$ $\operatorname{IgG}\left(\times 52.5\right.$ in A-431 $1_{\text {CEA-luc }}$ cells; $\times 37.2$ in SK-OV- $3_{1 \text { B9 }}$ cells $)$, highlighting again the lack of specificity of the NLS-mediated uptake. It has been proven that NLS or TAT peptides pass through plasma membranes in a non-receptor-dependent manner thanks to their highly cationic properties. In the context of our study, NLS or TAT peptides' addition to mAbs will generate a highly cationic macromolecule that will passively penetrate cells or accumulate onto negatively charged cell-surface proteins. Our results showed an increase of cell uptake when the mAb is conjugated with NLS or TAT peptides suggesting a correlation with the addition of NLS or TAT.

Moreover, the $\tilde{A}_{\text {nuclear }}$ versus $\tilde{A}_{\text {extranuc }}$ ratio with [111 In]In-trastuzumab-NLS $S_{5-10}$ was similar to that obtained with [ $\left.{ }^{111} \mathrm{In}\right] \mathrm{In}$-trastuzumab, suggesting that the NLS peptide did not improve the nuclear translocation of ${ }^{111}$ In-RIC once internalised in the cytoplasm (Figure 4). 
These results were supported by the fluorescent detection of immunoconjugate foci, mainly in the cytoplasm, and of very few NLS- and TAT-functionalised immunoconjugate foci in the nucleus. This low nuclear localisation might be due to endosomal-lysosomal entrapment, leading to RIC hydrolysis before they can reach the nucleus and might constitutes a key limiting factor for bringing AEEs into the nucleus. Several groups have developed attractive methods to promote endosomal escape. For instance, in hetero-functional constructs, a target-specific antibody is conjugated to cholic acid for endosomal escape and an NLS peptide is added for nuclear targeting [30,40]. Moreover, modular nanotransporters consist of a target-specific module, a diphtheria toxin translocation domain as endosomolytic module, an NLS peptide for transport to the nucleus, and the Escherichia coli haemoglobin-like protein as a carrier module $[28,40][28,41]$. These approaches should be further investigated to bypass Auger electron-carrier endosomal entrapment.

At this stage it was not possible to thoroughly investigate the relationship between clonogenic survival and activity uptake in the different cell compartments. Such study would require a comprehensive dosimetric approach (out of the scope of this study) and an assessment of the possible contribution of bystander effects. Moreover, it is important to keep in mind that the cell fractionation experiments were done using activities of 0.1 $\mathrm{MBq} / \mathrm{mL}$, and therefore, the only relationship that could be investigated would be with the clonogenic survival data measured at $0.5 \mathrm{MBq} / \mathrm{mL}$.

Interestingly, in a previous study [15], we showed that, in HCT116 cells exposed to [ $\left.{ }^{125} \mathrm{I}\right] \mathrm{I}-\mathrm{UdR}, \tilde{\mathrm{A}}_{\text {nuclear }}$ was about $441 \mathrm{~Bq} . \mathrm{s}$ and $\tilde{\mathrm{A}}_{\text {cellular }}$ was $455 \mathrm{~Bq} . \mathrm{s}$. Using the Bliss model and considering that cytotoxicity was only due to radioactivity in the nucleus, we calculated that $80 \%$ of cell killing was due to ${ }^{125}$ I located in the DNA [15], while here it was $20 \%$ (at $0.5 \mathrm{MBq} / \mathrm{mL}$, a test activity close to the one used for determining the $\tilde{\mathrm{A}}$ values and for which non-specific irradiation can be neglected) but with about $1.8(786 / 441)$ more decays. This would mean that one decay of ${ }^{125} \mathrm{I}$ is 7.2 times more efficient than one decay of ${ }^{111} \mathrm{In}$. If we consider that the energy deposited per decay and due to Auger electrons is about $8.7 \mathrm{keV}\left({ }^{125} \mathrm{I}\right)$ and $5.4 \mathrm{keV}\left({ }^{111} \mathrm{In}\right)$ in a $5 \mu \mathrm{m}$ diameter sphere, then ${ }^{125} \mathrm{I}$ deposits about 1.6 times more "high LET" energy than ${ }^{111} \mathrm{In}$. Moreover, a correction factor also needs to be introduced to counterbalance the localisation differences (nuclear but not bound to DNA versus nuclear and bound to DNA). As a relative biological effectiveness value of seven has been proposed when ${ }^{125} \mathrm{I}$ is bound to DNA [42,43] and of four [7] when unbound, then the factor that needs to be introduced here is 1.7. Additionally, HCT116 cells are about 1.8 times more radiosensitive than A-431 cells at a dose of 2 Gy [44]. In conclusion, ${ }^{111} \mathrm{In}$ incorporated in our RICs should be 8.8 times $(2.1 \times 1.6 \times 1.7 \times 1.8)$ less efficient than $\left[{ }^{125} \mathrm{I}\right] \mathrm{I}-\mathrm{UdR}$, a value that can be compared to the value of 7.2 found above.

The preliminary analysis of DNA damage yield ( $\gamma \mathrm{H} 2 \mathrm{AX}$ foci) in A-431 $1_{\text {CEA-luc }}$ cells exposed to $4 \mathrm{MBq} / \mathrm{mL}$ RIC showed that the highest levels of $\gamma \mathrm{H} 2 \mathrm{AX}$ foci were observed with [ $\left.{ }^{111} \mathrm{In}\right] \mathrm{In}$-trastuzumab-NLS ${ }_{5-10}$ and $\left[{ }^{111} \mathrm{In}\right] \mathrm{In}-\mathrm{IgG}-\mathrm{NLS}_{5-10}$, which are associated with the highest cytotoxicity and the highest $\tilde{\mathrm{A}}_{\text {nuclear }}$ and $\tilde{\mathrm{A}}_{\text {cellular values, although the transient }}$ DNA DSB yield cannot be strictly correlated with cell survival. As DNA breaks can be considered to be produced mostly by radiation, we investigated the relationship between the cumulative number of $\gamma \mathrm{H} 2 \mathrm{AX}$ foci measured over $144 \mathrm{~h}$ and the $\tilde{\mathrm{A}}_{\text {nuclear }}$ and $\tilde{\mathrm{A}}_{\text {cellular }}$ values. However, it must be kept in mind that DNA DSBs can also be produced by radioactivity contained in the culture medium or in neighbouring cells, two parameters not considered here. Moreover, the efficacy of DNA repair occurring at the same time as irradiation [16] could be influenced by the nature of DNA DSBs induced by radioactivity localised in or outside the nucleus. Despite these approximations, we found a relationship between the cumulative number of DSBs and the $\tilde{\mathrm{A}}_{\text {nuclear }}$ and $\tilde{\mathrm{A}}_{\text {cellular }}$ values, although none of these parameters seemed to fit the data best. It must be also noted that some DNA DSBs can be produced by a delayed mechanism involving cell membrane irradiation. We showed previously that Auger electron-mediated irradiation of the cell membrane induces lipid raft formation and the subsequent activation of signalling pathways, leading to the formation of ROS via NF-kB and DNA damage [15-17]. We could hypothesise that the high 
$\tilde{A}_{\text {extranuc }}$ value of [ $\left.{ }^{111} \mathrm{In}\right] \mathrm{In}$-trastuzumab-NLS 5 -10 (2412 Bq.s) is related to HER2 binding at the cell membrane, which is not possible with [111 In]In-IgG. However, this hypothesis needs to be further assessed because we do not know whether enough energy is deposited at the cell membrane.

\section{Conclusions}

In this study, we showed that the functionalisation of trastuzumab with $\mathrm{NLS}_{5-10}$ or $\mathrm{TAT}_{1-3}$ was accompanied by a rather limited increase in nuclear activity level and therefore, without a drastic decrease in clonogenic survival after exposure to ${ }^{111} \mathrm{In}$-RIC. We obtained similar results with the functionalised non-specific IgG, suggesting that the process is associated with a loss of specificity. This loss of specificity was stronger with $\mathrm{TAT}_{1-3}$ than NLS $_{5-10}$. This low nuclear uptake might be due to endosomal-lysosomal entrapment, leading to RIC hydrolysis before they reach the nucleus, and alternative methods to favour endosomal escape are required. Our results also indicate that the non-specific toxicity of ${ }^{111}$ In can be a limiting factor for AEE-based TRT, but this needs to be further assessed in vivo in mice for the reasons mentioned above. The comparison with [ ${ }^{125}$ I]I-UdR indicates that the amount of energy released in the nucleus by modulating activity uptake or by choosing a better AEE should be multiplied by 10 to obtain significant cell killing (e.g., 99\%).

Supplementary Materials: The following are available online at https://www.mdpi.com/article/10 .3390 / pharmaceutics13070980/s1, Figure S1: In vitro clonogenic cell death of unlabelled immunoconjugates. Clonogenic survival was assessed in A-431 $1_{\text {CEA-luc }}$ and SK-OV- $3_{1 \mathrm{~B} 9}$ cells 12 days after a $48 \mathrm{~h}$ exposure to trastuzumab, In-IgG, trastuzumab-NLS $5-10$, IgG-NLS $_{5-10}$, trastuzumab-TAT 1-3 $_{3}$ or IgG-TAT $_{1-3}$ (corresponding to the $\mathrm{mAb}$ mass added in the ${ }^{111}$ In-treated $4 \mathrm{MBq} / \mathrm{mL}$ groups). Data are the mean $\pm \mathrm{SD}$. Experiments were performed at least three times in triplicate. ${ }^{*} p \leq 0.05,{ }^{* *} p \leq 0.01$, *** $p \leq 0.001,{ }^{* * * *} p \leq 0.0001$.

Author Contributions: Conceptualization, M.B.I., A.P. and J.-P.P.; Formal analysis, M.B.I., A.P., S.P. and J.-P.P.; Funding acquisition, J.-P.P.; Investigation, M.B.I., A.P., B.T. and T.K.; Methodology, S.P., M.B.I., A.P., B.T.; Project administration, J.-P.P.; Supervision, A.P., T.K. and J.-P.P. All authors have read and agreed to the published version of the manuscript.

Funding: This work was supported by SIRIC Montpellier Cancer Grant INCa_Inserm_DGOS_12553, French National Research Agency as part of the Investissements d'Avenir program (ANR-10-LABX53-01) and Cancéropôle Grand Sud Ouest, Fondation ARC pour la Recherche. S.P. thanks the Fondation ARC for individual fellowship.

Institutional Review Board Statement: Not applicable.

Informed Consent Statement: Not applicable.

Conflicts of Interest: The authors declare no conflict of interest.

\section{References}

1. Brady, D.; O'Sullivan, J.M.; Prise, K.M. What is the role of the bystander response in radionuclide therapies? Front. Oncol. 2013, 3, 215. [CrossRef]

2. Pouget, J.-P.; Lozza, C.; Deshayes, E.; Boudousq, V.; Navarro-Teulon, I. Introduction to Radiobiology of Targeted Radionuclide Therapy. Front. Med. 2015, 2. [CrossRef] [PubMed]

3. Strosberg, J.; El-Haddad, G.; Wolin, E.; Hendifar, A.; Yao, J.; Chasen, B.; Mittra, E.; Kunz, P.L.; Kulke, M.H.; Jacene, H.; et al. Phase 3 Trial of ${ }^{177}$ Lu-Dotatate for Midgut Neuroendocrine Tumors. N. Engl. J. Med. 2017, 376, 125-135. [CrossRef]

4. Sartor, O.; de Bono, J.; Chi, K.N.; Fizazi, K.; Herrmann, K.; Rahbar, K.; Tagawa, S.T.; Nordquist, L.T.; Vaishampayan, N.; El-Haddad, G.; et al. Lutetium-177-PSMA-617 for Metastatic Castration-Resistant Prostate Cancer. N. Engl. J. Med. 2021, NEJMoa2107322. [CrossRef] [PubMed]

5. Bradley, E.W.; Chan, P.C.; Adelstein, S.J. The Radiotoxicity of Iodine-125 in Mammalian Cells: I. Effects on the Survival Curve of Radioiodine Incorporated into DNA. Radiat. Res. 1975, 64, 555. [CrossRef]

6. Kassis, A.I.; Adelstein, S.J.; Haydock, C.; Sastry, K.S.R.; McElvany, K.D.; Welch, M.J. Lethality of Auger electrons from the decay of bromine-77 in the DNA of mammalian cells. Radiat. Res. 1982, 90, 362. [CrossRef]

7. Kassis, A.I.; Fayad, F.; Kinsey, B.M.; Sastry, K.S.R.; Adelstein, S.J. Radiotoxicity of an 125 I-labeled DNA intercalator in mammalian cells. Radiat. Res. 1989, 118, 283. [CrossRef] 
8. Kassis, A.I.; Sastry, K.S.R.; Adelstein, S.J. Kinetics of uptake, retention, and radiotoxicity of 125 IUdR in mammalian cells: Implications of localized energy deposition by Auger processes. Radiat. Res. 1987, 109, 78. [CrossRef] [PubMed]

9. Chen, P.; Cameron, R.; Wang, J.; Vallis, K.A.; Reilly, R.M. Antitumor effects and normal tissue toxicity of 111In-labeled epidermal growth factor administered to athymic mice bearing epidermal growth factor receptor-positive human breast cancer xenografts. $J$. Nucl. Med. 2003, 44, 1469-1478.

10. Commerford, S.; Bond, V.; Cronkite, E.; Reincke, U. Radiotoxicity of intranuclear125I atoms not bound to DNA. Int. J. Radiat. Biol. Relat. Stud. Phys. Chem. Med. 1980, 37, 547-554. [CrossRef]

11. Costantini, D.L.; Chan, C.; Cai, Z.; Vallis, K.A.; Reilly, R.M. 111In-labeled Trastuzumab(Herceptin) modified with Nuclear Localization Sequences (NLS): An Auger electron-emitting radiotherapeutic agent for HER2/neu-amplified breast cancer. J. Nucl. Med. 2007, 48, 1357-1368. [CrossRef]

12. Costantini, D.L.; McLarty, K.; Lee, H.; Done, S.J.; Vallis, K.A.; Reilly, R.M. Antitumor effects and normal-tissue toxicity of 111In-nuclear localization sequence-trastuzumab in athymic mice bearing HER-positive human breast cancer xenografts. J. Nucl. Med. 2010, 51, 1084-1091. [CrossRef]

13. Anthony, L.B.; Woltering, E.A.; Espenan, G.D.; Cronin, M.D.; Maloney, T.J.; McCarthy, K.E. Indium-111-pentetreotide prolongs survival in gastroenteropancreatic malignancies. Semin. Nucl. Med. 2002, 32, 123-132. [CrossRef]

14. Pouget, J.-P.; Santoro, L.; Raymond, L.; Chouin, N.; Bardiès, M.; Bascoul-Mollevi, C.; Huguet, H.; Azria, D.; Kotzki, P.-O.; Pèlegrin, M.; et al. Cell membrane is a more sensitive target than cytoplasm to dense ionization produced by Auger electrons. Radiat. Res. 2008, 170, 192-200. [CrossRef]

15. Paillas, S.; Ladjohounlou, R.; Lozza, C.; Pichard, A.; Boudousq, V.; Jarlier, M.; Sevestre, S.; Le Blay, M.; Deshayes, E.; Sosabowski, J.; et al. Localized irradiation of cell membrane by Auger electrons is cytotoxic through oxidative stress-mediated nontargeted effects. Antioxid. Redox Signal. 2016, 25, 467-484. [CrossRef]

16. Piron, B.; Paillas, S.; Boudousq, V.; Pèlegrin, A.; Bascoul-Mollevi, C.; Chouin, N.; Navarro-Teulon, I.; Pouget, J.-P. DNA damagecentered signaling pathways are effectively activated during low dose-rate Auger radioimmunotherapy. Nucl. Med. Biol. 2014, 41, e75-e83. [CrossRef]

17. Paillas, S.; Boudousq, V.; Piron, B.; Kersual, N.; Bardies, M.; Chouin, N.; Bascoul-Mollevi, C.; Arnaud, F.-X.; Pèlegrin, A.; Navarro-Teulon, I.; et al. Apoptosis and p53 are not involved in the anti-tumor efficacy of 125I-labeled monoclonal antibodies targeting the cell membrane. Nucl. Med. Biol. 2013, 40, 471-480. [CrossRef] [PubMed]

18. Santoro, L.; Boutaleb, S.; Garambois, V.; Bascoul-Mollevi, C.; Boudousq, V.; Kotzki, P.-O.; Pèlegrin, M.; Navarro-Teulon, I.; Pèlegrin, A.; Pouget, J.-P. Noninternalizing monoclonal antibodies are suitable candidates for 125I radioimmunotherapy of small-volume peritoneal carcinomatosis. J. Nucl. Med. 2009, 50, 2033-2041. [CrossRef] [PubMed]

19. Ladjohounlou, R.; Lozza, C.; Pichard, A.; Constanzo, J.; Karam, J.; Le Fur, P.; Deshayes, E.; Boudousq, V.; Paillas, S.; Busson, M.; et al. Drugs that modify cholesterol metabolism alter the p38/JNK-mediated targeted and nontargeted response to Alpha and Auger radioimmunotherapy. Clin. Cancer Res. 2019, 25, 4775-4790. [CrossRef] [PubMed]

20. Quang, T.S.; Brady, L.W. Radioimmunotherapy as a novel treatment regimen: 125I-labeled monoclonal antibody 425 in the treatment of high-grade brain gliomas. Int. J. Radiat. Oncol. 2004, 58, 972-975. [CrossRef]

21. Galanis, E.; Goldberg, R.; Reid, J.; Atherton, P.; Sloan, J.; Pitot, H.; Rubin, J.; Adjei, A.A.; Burch, P.; Safgren, S.L.; et al. Phase I trial of sequential administration of raltitrexed (Tomudex) and 5-iodo-2'-deoxyuridine (IdUrd). Ann. Oncol. 2001, 12, 701-707. [CrossRef]

22. Li, L.; Quang, T.S.; Gracely, E.J.; Kim, J.H.; Emrich, J.G.; Yaeger, T.E.; Jenrette, J.M.; Cohen, S.C.; Black, P.; Brady, L.W. A phase II study of anti-epidermal growth factor receptor radioimmunotherapy in the treatment of glioblastoma multiforme. J. Neurosurg. 2010, 113, 192-198. [CrossRef] [PubMed]

23. Mariani, G.; Cei, A.; Collecchi, P.; Baranowska-Kortylewicz, J.; Abbeele, A.D.V.D.; Di Luca, L.; Di Stefano, R.; Viacava, P.; Ferdeghini, E.M.; Di Sacco, S. Tumor targeting in vivo and metabolic fate of 5-[iodine-125]iodo-2'-deoxyuridine following intratumoral injection in patients with colorectal cancer. J. Nucl. Med. 1993, 34, 1175-1183.

24. Filosofov, D.; Kurakina, E.; Radchenko, V. Potent candidates for targeted Auger therapy: Production and radiochemical considerations. Nucl. Med. Biol. 2021, 94-95, 1-19. [CrossRef]

25. Andersson, P.; Forssell-Aronsson, E.; Johanson, V.; Wängberg, B.; Nilsson, O.; Fjälling, M.; Ahlman, H. Internalization of indium-111 into human neuroendocrine tumor cells after incubation with indium-111-DTPA-D-Phe1-octreotide. J. Nucl. Med. 1996, 37, 2002-2006. [PubMed]

26. Cornelissen, B.; Hu, M.; McLarty, K.; Costantini, D.; Reilly, R.M. Cellular penetration and nuclear importation properties of 111In-labeled and 123I-labeled HIV-1 tat peptide immunoconjugates in BT-474 human breast cancer cells. Nucl. Med. Biol. 2007, 34, 37-46. [CrossRef] [PubMed]

27. Kersemans, V.; Cornelissen, B.; Minden, M.D.; Brandwein, J.; Reilly, R.M. Drug-resistant AML cells and primary AML specimens are killed by 111In-anti-CD33 monoclonal antibodies modified with nuclear localizing peptide sequences. J. Nucl. Med. 2008, 49, 1546-1554. [CrossRef]

28. Rosenkranz, A.; Slastnikova, T.A.; Karmakova, T.A.; Vorontsova, M.S.; Morozova, N.; Petriev, V.M.; Abrosimov, A.S.; Khramtsov, Y.V.; Lupanova, T.N.; Ulasov, A.V.; et al. Antitumor activity of Auger electron emitter 111In delivered by modular nanotransporter for treatment of bladder cancer with EGFR overexpression. Front. Pharmacol. 2018, 9, 1331. [CrossRef] 
29. Rosenkranz, A.A.; Slastnikova, T.A.; Durymanov, M.O.; Georgiev, G.P.; Sobolev, A.S. Exploiting active nuclear import for efficient delivery of Auger electron emitters into the cell nucleus. Int. J. Radiat. Biol. 2020, 1-11. [CrossRef]

30. Paquette, M.; Beaudoin, S.; Tremblay, M.-A.; Jean, S.; Lopez, A.F.; LeComte, R.; Guérin, B.; Bentourkia, M.; Sabbagh, R.; Leyton, J.V. NLS-cholic acid conjugation to IL-5R $\alpha$-specific antibody improves cellular accumulation and in vivo tumor-targeting properties in a bladder cancer model. Bioconjug. Chem. 2018, 29, 1352-1363. [CrossRef]

31. Vallis, K.A.; Reilly, R.M.; Scollard, D.; Merante, P.; Brade, A.; Velauthapillai, S.; Caldwell, C.; Chan, I.; Freeman, M.; Lockwood, G.; et al. Phase I trial to evaluate the tumor and normal tissue uptake, radiation dosimetry and safety of 111In-DTPA-human epidermal growth factor in patients with metastatic EGFR-positive breast cancer. Am. J. Nucl. Med. Mol. Imaging 2014, 4, 181-192.

32. Estupina, P.; Fontayne, A.; Barret, J.-M.; Kersual, N.; Dubreuil, O.; Le Blay, M.; Pichard, A.; Jarlier, M.; Pugnière, M.; Chauvin, M.; et al. The anti-tumor efficacy of 3C23K, a glyco-engineered humanized anti-MISRII antibody, in an ovarian cancer model is mainly mediated by engagement of immune effector cells. Oncotarget 2017, 8, 37061-37079. [CrossRef]

33. Sharma, S.K.; Lyashchenko, S.K.; Park, H.A.; Pillarsetty, N.V.K.; Roux, Y.; Wu, J.; Poty, S.; Tully, K.M.; Poirier, J.T.; Lewis, J.S. A rapid bead-based radioligand binding assay for the determination of target-binding fraction and quality control of radiopharmaceuticals. Nucl. Med. Biol. 2019, 71, 32-38. [CrossRef]

34. Pouget, J.-P.; Douki, T.; Richard, M.-J.; Cadet, J. DNA damage induced in cells by $\gamma$ and UVA radiation as measured by HPLC/GC-MS and HPLC-EC and comet assay. Chem. Res. Toxicol. 2000, 13, 541-549. [CrossRef]

35. Nuclear Energy Agency. PENELOPE-2006: A Code System for Monte Carlo Simulation of Electron and Photon Transport-Workshop Proceedings, Barcelona, Spain, 28 January-1 February 2019; OECD: Barcelona, Spain, 2019; ISBN 978-9264489950.

36. Lee, B.Q.; Nikjoo, H.; Ekman, J.; Jönsson, P.; Stuchbery, A.E.; Kibedi, T. A stochastic cascade model for Auger-electron emitting radionuclides. Int. J. Radiat. Biol. 2016, 92, 641-653. [CrossRef]

37. Tee, B.P.E.; Kibédi, T.; Lee, B.Q.; Vos, M.; Du Rietz, R.; Stuchbery, A.E. Development of a new database for Auger electron and X-ray spectra. In Proceedings of the EPJ Web of Conferences, Online, 6 April 2020; EDP Sciences: Les Ulis, France, 2020; Volume 232, p. 01006.

38. Görlich, D. Isolation of a protein that is essential for the first step of nuclear protein import. Cell 1994, 79, 767-778. [CrossRef]

39. Görlich, D.; Vogel, F.; Mills, A.D.; Hartmann, E.; Laskey, R.A. Distinct functions for the two importin subunits in nuclear protein import. Nat. Cell Biol. 1995, 377, 246-248. [CrossRef] [PubMed]

40. Beaudoin, S.; Rondeau, A.; Martel, O.; Bonin, M.-A.; Van Lier, J.E.; Leyton, J.V. ChAcNLS, a novel modification to antibodyconjugates permitting target cell-specific endosomal escape, localization to the nucleus, and enhanced total intracellular accumulation. Mol. Pharm. 2016, 13, 1915-1926. [CrossRef] [PubMed]

41. Karyagina, T.S.; Ulasov, A.V.; Slastnikova, T.A.; Rosenkranz, A.; Lupanova, T.N.; Khramtsov, Y.V.; Georgiev, G.P.; Sobolev, A.S. Targeted delivery of 111In into the nuclei of EGFR overexpressing cells via modular nanotransporters with anti-EGFR affibody. Front. Pharmacol. 2020, 11, 176. [CrossRef]

42. Yasui, L.S.; Hughes, A.; DeSombre, E.R. Relative biological effectiveness of accumulated 125IdU and 125I-estrogen decays in estrogen receptor-expressing MCF-7 human breast cancer cells. Radiat. Res. 2001, 155, 328-334. [CrossRef]

43. Makrigiorgos, G.M.; Berman, R.M.; Baranowska-Kortylewicz, J.; Bump, E.; Humm, J.L.; Adelstein, S.J.; Kassis, A.I. DNA damage produced in V79 cells by DNA-incorporated iodine-123: A comparison with iodine-125. Radiat. Res. 1992, 129, 309. [CrossRef] [PubMed]

44. Spiegelberg, D.; Dascalu, A.; Mortensen, A.C.; Abramenkovs, A.; Kuku, G.; Nestor, M.; Stenerlöw, B. The novel HSP90 inhibitor AT13387 potentiates radiation effects in squamous cell carcinoma and adenocarcinoma cells. Oncotarget 2015, 6, 35652-35666. [CrossRef] [PubMed] 